\title{
A Lifecycle Model to Evaluate Carbon Sequestration Potential and Greenhouse Gas Dynamics of Managed Grasslands
}

\author{
Marcia S. DeLonge, ${ }^{\star}$ Rebecca Ryals, and Whendee L. Silver
}

Ecosystem Sciences Division, Department of Environmental Science, Policy, and Management, University of California, 137 Mulford Hall No. 3114, Berkeley, California 94720, USA

\begin{abstract}
Soil amendments can increase net primary productivity (NPP) and soil carbon (C) sequestration in grasslands, but the net greenhouse gas fluxes of amendments such as manure, compost, and inorganic fertilizers remain unclear. To evaluate opportunities for climate change mitigation through soil amendment applications, we designed a field-scale model that quantifies greenhouse gas emissions $\left(\mathrm{CO}_{2}, \mathrm{CH}_{4}\right.$, and $\left.\mathrm{N}_{2} \mathrm{O}\right)$ from the production, application, and ecosystem response of soil amendments. Using this model, we developed a set of case studies for grazed annual grasslands in California. Sensitivity tests were performed to explore the impacts of model variables and management options. We conducted Monte Carlo simulations to provide estimates of the potential error associated with variables where literature data were sparse or spanned wide ranges. In the base case scenario, application of manure slurries led to net emissions of $14 \mathrm{Mg} \mathrm{CO}_{2} \mathrm{e} \mathrm{ha}^{-1}$ over a 3year period. Inorganic $\mathrm{N}$ fertilizer resulted in lower
\end{abstract}

Received 24 July 2012; accepted 25 February 2013; published online 16 April 2013

Electronic supplementary material: The online version of this article (doi:10.1007/s10021-013-9660-5) contains supplementary material, which is available to authorized users.

Author Contributions: MSD designed the study, performed research, and wrote the paper. RAR contributed data and expertise and provided input on the manuscript. WLS conceived of the study and contributed to research and manuscript development.

*Corresponding author; e-mail: marciadelonge@berkeley.edu greenhouse gas emissions than the manure $(3 \mathrm{Mg}$ $\mathrm{CO}_{2} \mathrm{e} \mathrm{ha}{ }^{-1}$ ), assuming equal rates of $\mathrm{N}$ addition and NPP response. In contrast, composted manure and plant waste led to large offsets that exceeded emissions, saving $23 \mathrm{Mg} \mathrm{CO}_{2} \mathrm{e} \mathrm{ha}{ }^{-1}$ over 3 years. The diversion of both feedstock materials from traditional high-emission waste management practices was the largest source of the offsets; secondary benefits were also achieved, including increased plant productivity, soil C sequestration, and reduced need for commercial feeds. The greenhouse gas saving rates suggest that compost amendments could result in significant offsets to greenhouse gas emissions, amounting to over $28 \mathrm{MMg} \mathrm{CO}_{2} \mathrm{e}$ when scaled to $5 \%$ of California rangelands. We found that the model was highly sensitive to manure and landfill management factors and less dependent on C sequestration, NPP, and soil greenhouse gas effluxes. The Monte Carlo analyses indicated that compost application to grasslands is likely to lead to net greenhouse gas offsets across a broad range of potential environmental and management conditions. We conclude that applications of composted organic matter to grasslands can contribute to climate change mitigation while sustaining productive lands and reducing waste loads.

Key words: annual grasslands; compost; greenhouse gas emission factors; fertilizer; global warming potential; rangelands. 


\section{INTRODUCTION}

Grasslands cover $25 \%$ of the Earth's land surface and are the dominant land-use globally (Asner and others 2004). These ecosystems occur in a biome characterized by periodic drought and high belowground allocation of plant tissues, leading to significant soil carbon (C) sequestration potential (Conant and others 2001, 2011). Despite the environmental and economic importance of these lands, soil degradation is widespread (nearly 2,000 Mha; Bridges and Oldman 1999; Bai and others 2008; FAO 2011) and many regions are losing soil C (Sanderman and Baldock 2010).

The application of soil amendments has been proposed as a means to increase net primary productivity (NPP) and soil C storage in grasslands (Paustian and others 1997; Conant and others 2001; Lal 2004a, b; Smith and others 2008; Cabrera and others 2009; Conant 2011; Ryals and Silver 2013). Many grasslands are limited by low nitrogen (N) availability, thus both inorganic and organic amendments rich in $\mathrm{N}$ are likely to increase NPP (Harpole and others 2007a, b). Commercial fertilizers applied to pasturelands and rangelands represent almost $10 \%$ of the total fertilizer land application in the US (>10.1 million ha in the US, USDA NASS 2009). Organic fertilizers include manure, compost, biosolids, and other green wastes and are widely used on rangelands to enhance forage production (Diacono and Montemurro 2010). Organic fertilizers have co-benefits that include increased soil fertility, soil water holding capacity, and drought resistance (Hudson 1994).

Manure is a form of organic fertilizer commonly added to pasture and cropland globally (81$128 \mathrm{Tg} \mathrm{N} \mathrm{y}^{-1}$, Potter and others 2010) and this practice is widespread in the U.S. (Cabrera and others 2009; Meyer and others 2011). Manure was used to treat 8.9 million ha of rangeland and pastureland nationwide in 2007 (USDA NASS 2009). Land application of manure disposes of waste while increasing soil nutrients, but has been implicated as a major contributor to greenhouse gas emissions from the livestock sector (Davidson 2009). Composts produced from manures and plant residues are an alternative to manure applications. Most composting systems maintain more aerobic conditions and lower greenhouse gas emissions compared to the moist and static conditions of many manure management facilities and landfills (Brown and others 2008), where high $\mathrm{CH}_{4}$ emissions can result from low redox potential. For example, in the U. S., landfills are the second largest source of anthropogenic $\mathrm{CH}_{4}$ (108 $\mathrm{Tg} \mathrm{CO}_{2} \mathrm{e}$, EPA 2012a). The opportunity to reduce wastes makes compost an attractive management strategy, but the overall benefits from compost depend on the emissions from composting, land application, and subsequent soil emissions. Under the best management practices, composting emissions are often considered negligible (EPA 2006; IPCC 2007). In practice, emissions from composting are variable (Anderson and others 2010; Larney and Hao 2007; Hao and others 2004), but guidelines are becoming established to minimize these emissions (Brown and others 2008; Fukumoto and others 2006). For example, using feedstocks with higher $\mathrm{C}$ to $\mathrm{N}$ ratios and lower moisture contents can reduce emissions (Brown and others 2008).

The potential for soil amendments to enhance soil organic matter content, increase NPP, sequester $\mathrm{C}$, and reduce atmospheric greenhouse gas concentrations makes them appealing for both climate change mitigation and land-use sustainability. Yet, the net greenhouse gas impacts from soil amendments remain poorly understood. The purpose of this study was to quantify the soil C sequestration potential and greenhouse gas emissions throughout the full life cycles of different soil amendments (compost, manures, and inorganic $\mathrm{N}$ fertilizer). We developed a model to calculate greenhouse gas emissions and offsets resulting from amendment production and the effects of soil amendment application on NPP, soil C storage, and factors associated with ruminant grazers. We included offsets from the diversion of materials from alternative fates, namely landfills and manure management facilities. We developed a set of case studies for the model based on grazed California grasslands and used these to test the sensitivity of the model output to key variables. We also performed Monte Carlo analyses to propagate uncertainty through the model and to evaluate the model response to a broader range of conditions. The model is unique in that it explicitly focuses on ecosystem impacts while including a range of inputs and outputs relevant to soil amendments.

\section{Materials AND Methods}

\section{Model Boundaries}

The model explores the net impacts of manure, compost, and inorganic fertilizer application to grasslands on ecosystem $\mathrm{C}$ and greenhouse gas dynamics (Figure 1). Model components for this study included amendment production and transportation, ecosystem response to amendments (NPP, soil C storage, soil greenhouse gas effluxes), 
impacts on grazers (feed availability, enteric fermentation), and offsets due to waste diversion. The model did not include emissions from milk or meat processing or details of animal management (dietary additives, emissions from confinement phase), which are treated elsewhere (for example, Rotz and others 2010; Pitesky and others 2009). The production costs of equipment were considered negligible. Emissions from landfill establishment (direct emissions or land-use change) and the production of landfill technologies were also not considered.

The model quantified the impacts of the three amendments types on the net greenhouse gas fluxes $\left(\mathrm{GHG}_{\text {net }}\right)$ as

$$
\mathrm{GHG}_{\text {net }}=\mathrm{GHG}_{\text {emissions }}-\mathrm{GHG}_{\text {sinks }}-\mathrm{GHG}_{\text {offsets }} \text {, }
$$

where $\mathrm{GHG}_{\text {net }}$ represents all emissions, sinks (direct removals of greenhouse gases from the atmosphere), and offsets (avoided emissions). The emissions component excluded biogenic $\mathrm{CO}_{2}$, which was considered atmospherically neutral (EPA 2006). Results are reported as net greenhouse gas fluxes in $\mathrm{CO}_{2}$-equivalents $\left(\mathrm{CO}_{2} \mathrm{e}\right)$ (IPCC 2007). The units $\mathrm{CO}_{2} \mathrm{e}$ represent the global warming potential (GWP), or relative radiative forcings, of greenhouse gases for different time periods, where $\mathrm{CO}_{2}$ has a GWP of 1 . We based the initial model runs on 100-year GWPs $\left(\mathrm{CH}_{4}=25 \mathrm{CO}_{2} \mathrm{e}, \mathrm{N}_{2} \mathrm{O}=\right.$ $298 \mathrm{CO}_{2} \mathrm{e}$ ) (IPCC 2007).

\section{Case Studies}

\section{Study Area}

In the case studies, we estimated the net greenhouse gas impact of a single application of amendments to Mediterranean annual grasslands. This initial case study (base case scenario) was developed using data from a field experiment that took place during 2008-2011 at a mesic coast range grassland (Marin County, California, $38.06^{\circ} \mathrm{N}$, $122.71^{\circ} \mathrm{W}$ ) and a drier valley grassland (Yuba
County, California, $39.24^{\circ} \mathrm{N}, 121.30^{\circ} \mathrm{W}$ ) (Table 1). During the field experiment, treatment (compost application) and control (unamended) plots were sampled for several ecosystem variables (NPP, biomass $\mathrm{C}$ content, soil $\mathrm{N}_{2} \mathrm{O}$, and $\mathrm{CH}_{4}$ effluxes) (Ryals and Silver 2013; Table 1). We developed a single case study representing California grasslands; the implications of site differences were explored within the sensitivity analyses. The field experiment only included compost amendments, therefore, we used literature values and theory to include and compare the impacts of manure and inorganic $\mathrm{N}$ amendments.

\section{Amendment Application Rates and Properties}

Amendment application rates were defined by the total $\mathrm{N}$ added. To minimize confounding effects from differential $\mathrm{N}$ fertilization as well as uncertainties from differing $\mathrm{N}$ mineralization rates, amendments were applied one-time only (Ryals and Silver 2013) at an equal rate of total $\mathrm{N}$ (250 kg N ha ${ }^{-1}$, Bouwman and others 2002) in the first case study; the impacts of different rates of total $\mathrm{N}$ addition were explored in alternative scenarios (described below). Physical and chemical properties (C:N, N concentration, bulk density, moisture content; Rynk 1992, Appendix A in Supplementary Material) were used to calculate the quantities required, as well as transportation costs. Compost for the initial case study was derived from manure and plant waste $(75 \%$ manure by mass). Plant waste consisted of $50 \%$ grasses and $50 \%$ yard waste leaves (Eleazer and others 1997). We assumed that plant and manure wastes lost $40 \%$ of their mass during composting (Larney and others 2000).

\section{Ecosystem Response to Soil Amendments}

Soil amendments impact $\mathrm{N}$ and $\mathrm{C}$ trace gas emissions (Chen and others 2011; Stehfest and Bouw-

\begin{tabular}{|c|c|c|}
\hline $\begin{array}{l}\text { Manure application } \\
\text { (Common practice) }\end{array}$ & $\begin{array}{l}\text { Compost application } \\
\text { (Alternate practice) }\end{array}$ & $\begin{array}{l}\text { Inorganic } \mathrm{N} \text { application } \\
\text { (Limited-resource case) }\end{array}$ \\
\hline $\begin{array}{l}\text { Manure stored } \\
\text { (e.g., slurry pond) }\end{array}$ & $\begin{array}{l}\text { Manure diverted } \\
\text { from storage }\end{array}$ & $\begin{array}{l}\text { No excess } \\
\text { manure }\end{array}$ \\
\hline $\begin{array}{l}\text { Manure to grazed } \\
\text { grassland }\end{array}$ & $\begin{array}{l}\text { Compost to } \\
\text { grazed grassland }\end{array}$ & $\begin{array}{l}\text { Inorganic } \mathrm{N} \text { to } \\
\text { grazed grasslanc }\end{array}$ \\
\hline
\end{tabular}

Figure 1. Key components (emissions and offsets) included in the quantification of net greenhouse gas flux associated with three different soil amendments: manure, compost, and inorganic fertilizer. 
Table 1. (a) Ecosystem Properties of Two Grasslands Used as the Basis for Initial Case Study and (b) Effect of a One-time Compost Addition to These Grasslands for 3 Years

\begin{tabular}{lll}
\hline (a) Ecosystem properties & Valley & Coast range \\
\hline Mean annual rainfall $\left(\mathrm{mm} \mathrm{y}^{-1}\right)$ & 730 & 950 \\
Rainfall during exp. $\left(\mathrm{mm} \mathrm{y}^{-1}\right)$ & $380,641,843$ & $771,1,050,1,163$ \\
Daily mean temperatures $\left({ }^{\circ} \mathrm{C}\right)$ & 2 (Jan.) & 6 (Jan.) \\
& 35 (Aug.) & 20 (Aug.) \\
& $0.13 \pm 0.13$ & $1.0 \pm 0.4$ \\
$\mathrm{Soil}_{2} \mathrm{O}\left(\mathrm{g} \mathrm{N}_{2} \mathrm{O} \mathrm{ha}^{-1} \mathrm{~d}^{-1}\right)$ & $-2.5 \pm 0.6$ & $-1.4 \pm 0.7$ \\
Soil $\mathrm{CH}_{4}\left(\mathrm{~g} \mathrm{CH}_{4} \mathrm{ha}^{-1} \mathrm{~d}^{-1}\right)$ & $592 \pm 31$ & $470 \pm 61$ \\
Aboveground NPP $\left(\mathrm{g} \mathrm{C} \mathrm{m}^{-2} 3 \mathrm{y}^{-1}\right)$ & $161 \pm 8$ & $177 \pm 13$ \\
Belowground NPP $(0-20 \mathrm{~cm})\left(\mathrm{g} \mathrm{C} \mathrm{m}^{-2} 3 \mathrm{y}^{-1}\right)$ & $29.1 \pm 1.7$ (wet) & $28.3 \pm 0.8$ (wet) \\
Mean daily soil moisture $(\%):$ wet, dry seasons & $22.2 \pm 1.3$ (dry) & $23.5 \pm 0.8$ (dry) \\
& $10.4 \pm 0.1$ (wet) & $12.2 \pm 1.0$ (wet) \\
Mean daily soil temp $\left({ }^{\circ} \mathrm{C}\right):$ wet, dry seasons & $26.0 \pm 0.4$ (dry) & $21.1 \pm 1.4$ (dry) \\
\hline (b) Treatment effect & Valley & Coastal \\
\hline Soil $\mathrm{N}_{2} \mathrm{O}\left(\mathrm{g} \mathrm{N}_{2} \mathrm{O}\right.$ ha & \\
Soil CH $\mathrm{d}_{4}\left(\mathrm{~g} \mathrm{CH}_{4} \mathrm{ha}^{-1} \mathrm{~d}^{-1}\right)$ & 0 & 0 \\
Aboveground NPP $\left(\mathrm{g} \mathrm{C} \mathrm{m}^{-2} \mathrm{y}^{-1}\right)$ & 0 & 0 \\
Belowground NPP $\left(\mathrm{g} \mathrm{C} \mathrm{m}^{-2} \mathrm{y}^{-1}\right)$ & $+145 \pm 17$ & $+54 \pm 3$ \\
Mean daily soil moisture $(\%):$ wet, dry seasons & $+11.1 \pm 2.0$ & $+13.9 \pm 3.0$ \\
& $+1.0 \pm 0.9$ (wet) & $+0.3 \pm 0.4$ (wet) \\
Mean daily soil temp $\left({ }^{\circ} \mathrm{C}\right):$ wet, dry seasons & $+0.6 \pm 0.6$ (dry) & $-0.3 \pm 0.5$ (dry) \\
& $+0.40 \pm 0.24$ (wet) & $-0.04 \pm 0.18$ (wet) \\
\hline
\end{tabular}

man 2006; Davidson 2009), as well as C uptake via NPP (Diacono and Montemurro 2010; Stavast and others 2005). Soil $\mathrm{N}_{2} \mathrm{O}$ emissions occur both directly (through nitrification and denitrification) and indirectly (via volatilization and redeposition, or leaching and runoff) (De Klein and others 2006). Recently, a regression model was applied globally to estimate that $2.5 \%$ of synthentic- $\mathrm{N}$ and $2.0 \%$ of manure- $\mathrm{N}$ is ultimately converted to $\mathrm{N}_{2} \mathrm{O}$ (Davidson 2009). These findings agreed well with recommended methodologies for calculating $\mathrm{N}_{2} \mathrm{O}$ emissions from fertilizers (De Klein and others 2006), which we adopt here to account for direct and indirect sources separately. We assumed that $1.0 \%$ of added inorganic or manure- $\mathrm{N}$ and $0.25 \%$ of compost- $\mathrm{N}$ was converted directly to $\mathrm{N}_{2} \mathrm{O}$ (Ryals and Silver 2013; Dalai and others 2009a, b; Paul and others 1993). Leaching losses from inorganic fertilizer were estimated as $0.0075 \mathrm{~kg} \mathrm{~N}_{2} \mathrm{O}-\mathrm{N} \mathrm{kg}^{-1}$ leachate- $\mathrm{N}$, where leachate contained $0.3 \mathrm{~kg} \mathrm{~N} \mathrm{~kg}^{-1}$ amendment-N (Mosier and others 1998); leaching rates were lower (by 75\%) for manure-N (Kramer and others 2006) and there were no significant leaching losses from compost-amended lands due the slower $\mathrm{N}$ release rate of composted materials. Indirect $\mathrm{N}_{2} \mathrm{O}$ from volatilization occurred at rates of $0.01 \mathrm{~kg} \mathrm{~N}_{2} \mathrm{O}-\mathrm{N} \mathrm{kg}^{-1}$ volatilized- $\mathrm{N}$, where the fraction of amendment-N volatilized was $0.1,0.2$, and
0.05 for inorganic fertilizer, manure, and compost, respectively (De Klein and others 2006). Nitrous oxide emissions depend on the quantity and quality of the $\mathrm{N}$ inputs as well as environmental factors (Stehfest and Bouwman 2006; Lesschen and others 2011), thus site-specific emissions estimates of $\mathrm{N}_{2} \mathrm{O}$ should be adopted whenever possible (Kendall and Chang 2009).

Grasslands are typically a net sink for $\mathrm{CH}_{4}$ (Le Mer and Roger 2001), with levels of annual uptake averaging approximately $1.5 \mathrm{~kg} \mathrm{C} \mathrm{ha} \mathrm{y}^{-1} \mathrm{y}^{-1}$ for temperate, fine texture soils, but up to $3.5 \mathrm{~kg} \mathrm{C}$ ha ${ }^{-1} \mathrm{y}^{-1}$ in coarser grassland soils (Del Grosso and others 2000). Fertilization of grasslands has been shown to reduce levels of $\mathrm{CH}_{4}$ uptake (Mosier and others 1991), with oxidation rates suppressed to $25-100 \%$ of unfertilized grasslands (Del Grosso and others 2000). During wet periods, unfertilized grasslands can become a source of $\mathrm{CH}_{4}$ (1.6 kg C ha ${ }^{-1} \mathrm{y}^{-1}$, Tenuta and others 2010), with fertilized areas emitting relatively more $\mathrm{CH}_{4}$ (by $69-118 \%$, Tenuta and others 2010). The mechanisms for $\mathrm{CH}_{4}$ uptake and emissions are not entirely understood, and in rare cases $\mathrm{N}$ fertilization can increase $\mathrm{CH}_{4}$ emissions (Bodelier and Laanbroek 2004). Fertilization does not always change $\mathrm{CH}_{4}$ fluxes relative to unamended grasslands; for example, this has been the case following compost 
amendments (Ryals and Silver 2013; Chen and others 2011) and manure slurries (Glatzel and Stahr 2001). For the initial case study, we assumed a $25 \%$ reduction in $\mathrm{CH}_{4}$ consumption following inorganic fertilizer and manure additions, and no impact to $\mathrm{CH}_{4}$ effluxes following compost addition. Soil $\mathrm{CO}_{2}$ emissions are likely to increase as $\mathrm{C}$-based amendments decompose; we assumed that these emissions would have occurred regardless of the amendment's fate (that is, no priming effect), and thus they are not included here.

Based on field data, we estimated that compost amendments enhanced aboveground biomass by $56 \%\left(0.099 \mathrm{~kg} \mathrm{C} \mathrm{m}^{-2}\right)$ and belowground biomass by $21 \%\left(0.012 \mathrm{~kg} \mathrm{C} \mathrm{m}^{-2}\right)$ where biomass had a C concentration of $41 \%$ (Ryals and Silver 2013). In the model, $\mathrm{N}$ is the limiting nutrient and equal $\mathrm{N}$ inputs had equivalent impacts on NPP (Kramer and others 2006). Organic N mineralizes at slower rates than inorganic $\mathrm{N}$, thus equal total $\mathrm{N}$ additions do not necessarily translate to equal plant-available $\mathrm{N}$ additions. In the base case scenario, we applied equal total $\mathrm{N}$ and assumed equivalent responses when considered over the 3-year period. Annual grasslands are commonly grazed to a fixed amount of residual biomass; therefore, we assumed that extra aboveground biomass was mostly consumed $(90 \%)$.

The amount of $\mathrm{C}$ added from enhanced belowground biomass that is stored in long-term pools, termed the $C$ sink efficiency, can be estimated based on a humification factor. Roots can have humification factors ranging from 0.16 to 0.30 (Plénet and others 1993) or up to 0.35 (Katterer and others 2011). As a first approximation, we assumed that $20 \%$ of added belowground biomass $\mathrm{C}$ from all amendments contributed to long-term pools (remaining in the system for 20 years). As $C$ in the soil amendments was pre-existing, these direct additions were not considered a sink in this study. While direct additions of $\mathrm{C}$ can significantly enhance soil C pools (Ryals and others, in review-b; Cavigelli and others 2009) and have been considered a sink in other studies (Tian and others 2009; Brown and others 2011), we chose instead to account for this relative $\mathrm{C}$ gain primarily by defining avoided $\mathrm{C}$ losses as an offset. To avoid double counting, we conservatively omitted the direct C additions from our model.

\section{Grazer Impacts}

An average stocking rate (grazers $\mathrm{ha}^{-1}$ ) was used to approximate the impact of a change in NPP on the demand for commercial feed, grazer emissions, and manure production. Although grazing intensity depends on numerous factors and remains poorly defined (Holecheck and others 1999), stocking rates for dairies are often between 0.2 and 4 cows ha ${ }^{-1}$ (Allard and others 2007; McDowell and others 2008; Powell and others 2002; Stout and others 2000). We assumed a low stocking rate of 0.5 cow ha ${ }^{-1}$ across all treatments.

Greenhouse gas offsets from avoiding commercial feeds (due to enhanced forage production) depend on feed variety. We assumed that forage production replaced an equal mass of dry matter intake otherwise obtained from hay and corn silage ( $50 \%$ of each). Reduced demand for these crops represented an offset that included the net greenhouse gas flux from inorganic fertilizer production (4.01 kg CO $\mathrm{e} \mathrm{kg}^{-1} \mathrm{~N}$, Davis and Haglund 1999), the production of other additives (17.2 $\mathrm{kg} \mathrm{CO}_{2} \mathrm{e} \mathrm{kg}^{-1}$ herbicide, $18.0 \mathrm{~kg} \mathrm{CO}_{2} \mathrm{e} \mathrm{kg}^{-1}$ insecticide, West and Marland 2002; Lal 2004c), direct and indirect soil $\mathrm{N}_{2} \mathrm{O}$ emissions from fertilizeramended cropland (at rates described above), and transportation. Emissions from farm operations were included and were based on estimates of the $\mathrm{C}$ costs of plowing, planting, amendment application, harvesting, and baling $\left(31.8 \mathrm{~kg} \mathrm{C} \mathrm{ha}^{-1}\right.$, Adler and others 2007). Dry matter from feeds and additive rates were estimated using national averages (Benbrook and others 2010; USDA NASS 2011).

The impact of the dietary change from commercial feed to local pasture on grazer emissions was also estimated. We assumed that pasture consumption replaced a portion of dry matter intake (19.7 $\mathrm{kg} \mathrm{d}^{-1}$, Ellis and others 2010) previously consumed through commercial feed. The increase in $\mathrm{CH}_{4}$ emissions from enteric fermentation $\left(\mathrm{dCH}_{4 \mathrm{EF}}, \mathrm{kg} \mathrm{d}^{-1}\right)$ due to replacement of more readily digestible grains with pasture was predicted based on Ellis and others (2007)

$$
\mathrm{CH}_{4 \mathrm{EnF}}=[(\mathrm{Frg} \times 0.14)+8.56] / 55.65,
$$

where Frg is the percent dry matter intake from pasture; the difference between $\mathrm{CH}_{4 \mathrm{EnF}}$ with the original diet (68\% pasture, Ellis and others 2007) and the new diet was obtained to determine $\mathrm{dCH}_{4 \mathrm{EF}}$. In the case study, we assumed that these dietary impacts lasted for the same duration as the enhanced NPP effect (3 years).

\section{Transportation}

Distances between the farm and other locations (materials, feed, fields) were assigned to approximate transportation emissions. We assumed that plant waste, feed, and fertilizers were available at a standard distance $(20 \mathrm{~km})$ from the farm (EPA 2006) and that manure was available locally 
$(5 \mathrm{~km})$. Once on site, amendments were transported equal distances $(5 \mathrm{~km})$ for application. We used the gas mileage (5.9 mpg, EPA 2008), volume (40 yd), and weight capacity (36 Mg, CDOT 2012) of a standard heavy-duty diesel truck. Emissions from both fuel production (Beer and others 2002) and consumption (EPA 2008) were included.

\section{Manure Management}

A manure management emission factor (EF) was used to calculate $\mathrm{CH}_{4}$ emissions from manure handling. This EF provides the fraction of total potential $\mathrm{CH}_{4}$ emitted from the storage system (EPA 2012b). Storage systems lead to different amounts of $\mathrm{CH}_{4}$ production depending on several factors, including oxygen availability, moisture, and temperature (Brown and others 2008; Dong and others 2006). Solid storage has a low EF (0.04), whereas slurry pits and lagoons are higher $(0.35$ and 0.74 on average, respectively). Substantial variability in EFs has been reported within and across systems, with EFs for slurry pits and anaerobic lagoons ranging nationally between 0.15 and 0.62 and 0.5 and 0.8 , respectively (EPA 2012b). We assumed an EF of 0.35 for the initial case study, representative of a slurry pit, a common practice in California (Meyer and others 2011). Total emissions from manure management practices also depend on the duration of storage. In the case study, we reduced the predicted emissions from manure management by $15 \%$ to account for a shortened storage period prior to land application; this reduction in $\mathrm{CH}_{4}$ emissions was applied to both the manure (emission) and compost (offset) treatments.

\section{Emissions from Amendment Production}

Emissions from production were calculated for each amendment. For manure, the production process included transportation and storage emissions (slurry pond; EPA 2006; IPCC 2007). Emissions from compost production included material transportation, construction, and composting emissions. To estimate construction emissions, we approximated the hours of machine use per truckload. Equipment fuel was used at a fixed rate (0.048 gallons diesel $\mathrm{h}^{-1}$, Downs and Hansen 1998), and the net greenhouse gas flux was calculated at the same rates used for transportation. Greenhouse gas emissions from compost were calculated from piles shaped as windrows (1.8-m tall $\times 1.2-\mathrm{m}$ wide). We used relatively low, but non-zero, rates of $\mathrm{CH}_{4}\left(0.5 \mathrm{~kg} \mathrm{~m}^{-2}\right)$ and $\mathrm{N}_{2} \mathrm{O}$ $\left(0.01 \mathrm{~kg} \mathrm{~m}^{-2}\right)$ emissions for the initial case study; these emission rates approach the negligible emissions expected from optimal conditions (EPA 2006). Emissions from the production of inorganic $\mathrm{N}$ fertilizer depend on the $\mathrm{N}$ form and the production process (Wood and Cowie 2004; ammonium nitrate: $2.99-7.11 \mathrm{~kg} \mathrm{CO}_{2} \mathrm{e} \mathrm{kg}^{-1} \mathrm{~N}$; urea: $\left.0.913-4.02 \mathrm{~kg} \mathrm{CO}_{2} \mathrm{e} \mathrm{kg}^{-1} \mathrm{~N}\right)$. We used a midrange value of $4.01 \mathrm{~kg} \mathrm{CO}_{2} \mathrm{e} \mathrm{kg}^{-1} \mathrm{~N}$ (Davis and Haglund 1999; Wood and Cowie 2004).

\section{Offsets from Amendment Production}

Offsets from compost production, which was used to represent a non-traditional waste management practice, included the diversion of plant waste from a landfill and the diversion of manure from a specific manure management system. In contrast, the manure amendment scenario in this model was used to represent a practice where manure was stored in a traditional management system (that is, a slurry) prior to land application. Thus, for manure amendments, there were no offsets attributed to waste diversion. However, changing the manure management system or decreasing the length of manure storage time prior to land application would reduce the predicted emissions associated with manure application, as mentioned above. No waste offsets were included in the inorganic fertilizer production.

Composted plant waste was diverted from landfills and represented greenhouse gas offsets. The potential $\mathrm{CH}_{4}$ loss from landfilling depends on waste composition. Based on the composition described above, $11 \%$ of the plant $\mathrm{C}$ would have been lost as $\mathrm{CH}_{4}$ in a landfill (Eleazer and others 1997). Some landfills capture $\mathrm{CH}_{4}$ and use the gas for utilities, reducing net landfill emissions. To account for these technologies, we applied a capture rate of $50 \%$ and a utilities credit of $0.14 \mathrm{~kg} \mathrm{CO}_{2} \mathrm{e} \mathrm{kg}^{-1}$ $\mathrm{CO}_{2} \mathrm{e}-\mathrm{CH}_{4}$ captured (EPA 2006). We excluded biogenic $\mathrm{CO}_{2}$ losses, but included $\mathrm{CO}_{2}$ from fuel production and consumption. Landfilled materials can require less maintenance than compost piles; we estimated that landfilling required $50 \%$ of the fuel needed for composting (EPA 2006).

\section{Alternative Model Scenarios and Uncertainty Analyses}

We developed additional model case studies to explore the impacts of amendments under a wide range of ecosystem and management conditions (Table 2). For example, we considered the potential for long-term impacts on ecosystem NPP to enhance soil $\mathrm{C}$ sequestration. Although our initial case study was based on a field experiment that 
Table 2. Alternative Scenarios Relative to Initial Case Study

\begin{tabular}{|c|c|c|c|}
\hline Scenario description & Variable modified & Note* & Value \\
\hline \multirow{2}{*}{$\begin{array}{l}\text { Global warming potential over shorter ( } 20 \text { - } \\
\text { year) timeframe }\end{array}$} & \multirow[t]{2}{*}{$\mathrm{GWP}\left(\mathrm{CO}_{2} \mathrm{e}\right)$} & $\mathrm{N}_{2} \mathrm{O}$ & 289 \\
\hline & & $\mathrm{CH}_{4}$ & 72 \\
\hline $\begin{array}{l}\text { Longer NPP effect from single application of } \\
\text { all amendments }\end{array}$ & \multicolumn{2}{|l|}{ NPP effect (years) } & 20 \\
\hline $\begin{array}{l}\text { Longer NPP effect, but no change in enteric } \\
\text { fermentation due to diet change }\end{array}$ & \multicolumn{2}{|l|}{ Enteric fermentation $\left(\mathrm{CO}_{2} \mathrm{e} \mathrm{ha}{ }^{-1}\right)$} & 0 \\
\hline \multirow{3}{*}{$\begin{array}{l}\mathrm{N} \text { addition rates unequal for different } \\
\text { amendments }\end{array}$} & \multirow[t]{3}{*}{$\mathrm{N}$ addition rate $\left(\mathrm{kg} \mathrm{N}_{\mathrm{ha}}^{-1}\right)$} & $\mathrm{C}$ & 1,250 \\
\hline & & M & 250 \\
\hline & & INF & 125 \\
\hline Manure stockpile (vs. slurry) & $\begin{array}{l}\text { Manure management emission } \\
\text { factor }(-)\end{array}$ & & 0.05 \\
\hline \multirow[t]{2}{*}{ Production emissions non-negligible } & \multirow[t]{2}{*}{ Compost emissions $\left(\mathrm{kg} \mathrm{m}^{-2}\right)$} & $\mathrm{CH}_{4}$ & 5.0 \\
\hline & & $\mathrm{N}_{2} \mathrm{O}$ & 0.1 \\
\hline Optimal capture technology & Landfill $\mathrm{CH}_{4}$ capture (\%) & $\mathrm{C}$ & 100 \\
\hline No utilities credit from landfill $\mathrm{CH}_{4}$ (vs. avg.) & 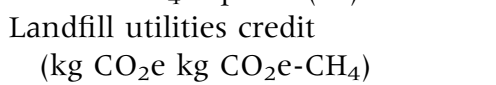 & $\mathrm{C}$ & 0 \\
\hline Compost largely plant waste & Compost (\% manure) & $\mathrm{C}$ & 25 \\
\hline Compost hauled further & Hauling distance $(\mathrm{km})$ & $\mathrm{C}$ & 500 \\
\hline
\end{tabular}

* Changes apply only to the case for compost (C), manure (M), or inorganic fertilizer (INF) where indicated

showed 3 years of enhanced NPP due to an amendment application (Ryals and Silver 2013), model results suggest that the effect could be sustained for up to 20 years following a one-time-only application (Ryals and others, in review-a). Thus, we explored a 20-year impact on NPP, as well as a 20 -year impact on soil trace gas emissions. We also considered the 20-year scenario with no increase in enteric fermentation due to the dietary change (Boadi and others 2004).

Among management scenarios, we evaluated the case where amendments were added at different rates: compost was added at $1,250 \mathrm{~kg} \mathrm{~N} \mathrm{ha}^{-1}$ $(1.27 \mathrm{~cm}$, Ryals and Silver 2013), but manure and inorganic fertilizer were added at 250 and $125 \mathrm{~kg} \mathrm{~N} \mathrm{ha}^{-1}$, respectively. Nitrogen is generally highly labile in manure and inorganic fertilizers and thus these amendments are generally applied at rates below $250 \mathrm{~kg} \mathrm{~N} \mathrm{ha}^{-1}$ (Bouwman and others 2002). In contrast, composted materials contain $\mathrm{N}$ that is more complexed leading to slower mineralization rates (Eghball 2000; Sikora and Szmidt 2001; Ryals and Silver 2013), which can require higher application rates.

Differences in management technologies and scales could also impact the effects of the practice. Some manure management practices produce fewer emissions than slurry systems; thus, we considered the case where the default system was a stockpile $(E F=0.05)$. Similarly, because some landfills can capture more $\mathrm{CH}_{4}$, we evaluated the effect of a $100 \%$ capture rate. Emissions from composting are not negligible in all cases, so we included a scenario where $\mathrm{CH}_{4}$ and $\mathrm{N}_{2} \mathrm{O}$ emissions were significantly greater (10 times larger). Widespread adoption of compost amendments could encourage large-scale production. We therefore estimated the impact of transporting compost over large distances $(500 \mathrm{~km})$. Finally, to consider how the GWP values influenced our results, we used the 20-year GWPs $\left(\mathrm{CH}_{4}=72 \mathrm{CO}_{2} \mathrm{e}, \mathrm{N}_{2} \mathrm{O}=289 \mathrm{CO}_{2} \mathrm{e}\right)$.

We performed sensitivity tests to identify the factors that had the largest impact on the model output. The effect of deviations of initial case study values from -90 to $500 \%$ of initial values was calculated (Appendix B in Supplementary Material). For most of these analyses, one variable was adjusted at a time while other values were held constant. However, some factors were covaried to reveal a wider range of potential impacts. For example, to investigate the sensitivity of results to a range of ecosystem characteristics, we covaried the annual expected change to NPP with both the duration of the NPP effect and the C sink efficiency. To evaluate a broader range of impacts related to management, we covaried the percentage of manure used in the compost with both the manure management factor and the landfill $\mathrm{CH}_{4}$ capture rate.

To evaluate the uncertainty associated with variables used in the model, we performed Monte Carlo simulations based on the initial case study. Values of several model variables were assigned probability distribution functions based on values 
from the literature (Table 3; Appendix A in Supplementary Material). Values for each variable were randomly assigned based on these distribution functions and 10,000 independent simulations were run. This set of Monte Carlo simulations was then used to further explore the uncertainties of the model and likely outcomes from the model scenarios. Results of the Monte Carlo simulations are presented as mean \pm 1 standard error.

\section{RESUlts}

\section{Initial Case Study for Annual Grasslands}

Compost applications in the initial case study yielded a net greenhouse gas flux of $-22.6 \mathrm{Mg} \mathrm{CO}_{2} \mathrm{e} \mathrm{ha}^{-1}$ over 3 years (Figure 2). This net reduction was largely due to offsets from avoided emissions from a manure slurry system and a landfill. The $\mathrm{C}$ sink resulting from increased NPP contributed a savings of $0.3 \mathrm{Mg} \mathrm{CO}_{2} \mathrm{e} \mathrm{ha}{ }^{-1}$. The emissions attributed to compost production and application in the initial case study were approximately $3.7 \mathrm{Mg} \mathrm{CO}_{2} \mathrm{e} \mathrm{ha}^{-1}$,

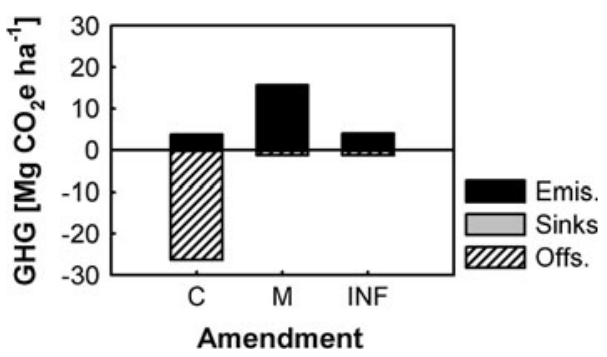

Figure 2. Net greenhouse gas flux $\left(\mathrm{GHG}_{\text {net }}\right)$ from the production and land application of compost (C), slurry manure $(\mathrm{M})$, and inorganic $\mathrm{N}$ fertilizer (INF) to grazed annual grasslands. $\mathrm{GHG}_{\text {net }}$ per hectare is partitioned into emissions, sinks, and offsets. Negative values represent sinks and offsets.

which was due in large part to the assumed dietary changes of livestock.

Manure application was a large net source of 14.4 $\mathrm{Mg} \mathrm{CO} \mathrm{e} \mathrm{ha}^{-1}$ (Figure 2), primarily due to high emissions from a slurry storage system prior to land application (15.0 $\mathrm{Mg} \mathrm{CO}_{2} \mathrm{e} \mathrm{ha}{ }^{-1}$ ). The emissions from transportation and application were

Table 3. Model Parameterization for Grassland Case Study and Uncertainty Analysis

\begin{tabular}{|c|c|c|c|c|c|c|}
\hline \multirow[t]{2}{*}{ Variable } & \multirow[t]{2}{*}{ Note* } & \multicolumn{2}{|c|}{ Case study } & \multicolumn{3}{|c|}{$\begin{array}{l}\text { Uncertainty } \\
\text { analysis descriptors }\end{array}$} \\
\hline & & Value & References & Distrib. & $\mu, \min$ & $\sigma, \max$ \\
\hline \multirow[t]{2}{*}{ Global warming potential $(\mathrm{GWP})\left(\mathrm{CO}_{2} \mathrm{e}\right)$} & $\mathrm{N}_{2} \mathrm{O}$ & 298 & a & Normal & 298 & 64 \\
\hline & $\mathrm{CH}_{4}$ & 25 & & Normal & 25 & 5 \\
\hline \multirow{3}{*}{ Soil $\mathrm{N}_{2} \mathrm{O}$ increase (direct) $\left(\mathrm{kg} \mathrm{N} \mathrm{kg}^{-1}\right.$ added-N) } & $\mathrm{C}$ & 0.003 & $\mathrm{~b}$ & Lognormal & -6.1 & 0.5 \\
\hline & M & 0.01 & c & Lognormal & -4.7 & 0.6 \\
\hline & INF & 0.01 & c & Lognormal & -4.7 & 0.6 \\
\hline \multirow[t]{2}{*}{ Increased aboveground (AG), belowground (BG) (NPP) (\%) } & $\mathrm{AG}$ & 55 & $\mathrm{~b}$ & Normal & 55 & 11 \\
\hline & BG & 23 & & Normal & 23 & 4 \\
\hline Soil trace gas (TG) effect (years) & & 1 & $\mathrm{~b}$ & Exponential & 1.4 & $\mathrm{n} / \mathrm{a}$ \\
\hline NPP effect (years) & & 3 & $\mathrm{~b}$ & Exponential & 4 & $\mathrm{n} / \mathrm{a}$ \\
\hline Enteric ferm. factor (fraction of $\mathrm{dCH}_{4 \mathrm{EF}}$ from Eq. 2) & & 1 & $\mathrm{~d}$ & Normal & 0 & 0.20 \\
\hline C sink efficiency $\left(\mathrm{kg} \mathrm{C} \mathrm{kg}^{-1}\right.$ added BG C) & & 0.2 & $\mathrm{e}$ & Lognormal & -1.70 & 0.35 \\
\hline $\mathrm{N}$ addition rate $\left(\mathrm{kg} \mathrm{N} \mathrm{ha}^{-1}\right)$ & & 250 & $\mathrm{f}$ & Lognormal & 5.40 & 0.45 \\
\hline Manure management emission factor $(-)$ & $\mathrm{M}, \mathrm{C}$ & 0.35 & $\mathrm{~g}$ & Lognormal & -1.00 & 0.25 \\
\hline Manure management time factor $(-)$ & $\mathrm{M}, \mathrm{C}$ & 0.85 & & Exponential & 0.1 & $\mathrm{n} / \mathrm{a}$ \\
\hline Inorganic $\mathrm{N}$ production $\left(\mathrm{kg} \mathrm{CO}_{2} \mathrm{e} \mathrm{kg}^{-1} \mathrm{~N}\right)$ & & 4.01 & $\mathrm{~h}$ & Normal & 4.01 & 1.00 \\
\hline \multirow[t]{2}{*}{ Compost emissions $\left(\mathrm{kg} \mathrm{m}^{-2}\right)$} & $\mathrm{CH}_{4}$ & 0.50 & i & Lognormal & -0.2 & 0.8 \\
\hline & $\mathrm{N}_{2} \mathrm{O}$ & 0.01 & & Lognormal & -4.0 & 0.75 \\
\hline Landfill waste $\mathrm{CH}_{4}-\mathrm{C}$ loss (\% initial C) & $\mathrm{C}$ & 11 & $\mathrm{j}$ & Lognormal & 2.25 & 0.5 \\
\hline Landfill $\mathrm{CH}_{4}$ capture (\%) & $\mathrm{C}$ & 50 & i & Normal & 50 & 12 \\
\hline Landfill utilities credit $\left(\mathrm{kg} \mathrm{CO}_{2} \mathrm{e} \mathrm{kg}{ }^{-1} \mathrm{CO}_{2} \mathrm{e}-\mathrm{CH}_{4}\right)$ & $\mathrm{C}$ & 0.14 & $\mathrm{i}$ & Normal & 0.14 & 0.03 \\
\hline Compost (\% manure) & $\mathrm{C}$ & 75 & & Uniform & 0 & 100 \\
\hline Hauling distance $(\mathrm{km})$ & $\mathrm{C}$ & 5 & & Exponential & 5 & $\mathrm{n} / \mathrm{a}$ \\
\hline Farm operations $\left(\mathrm{kg} \mathrm{C} \mathrm{ha}{ }^{-1}\right)$ & & 31.8 & $\mathrm{k}$ & Normal & 31.8 & 6.4 \\
\hline
\end{tabular}

(a) IPCC (2007), (b) Ryals and Silver (2013), (c) De Klein and others (2006), (d) Ellis and others (2007), (e) Plénet and others (1993), (f) Bouwman and others (2002), (g) EPA (2012b), (h) Davis and Haglund (1999), (i) EPA (2006), (j) Eleazer and others (1997), (k) Adler and others (2007).

*Values apply only to the case for compost $(C)$, manure $(M)$, or inorganic fertilizer (INF) where indicated 
$0.6 \mathrm{Mg} \mathrm{CO}_{2} \mathrm{e} \mathrm{ha}{ }^{-1}$, which were lower than those from compost because we assumed that manure was available on site and that plant waste required longer transport distances. We assumed that all amendments impacted NPP equally, thus the C sink was the same as for compost $\left(0.3 \mathrm{Mg} \mathrm{CO}_{2} \mathrm{e} \mathrm{ha}^{-1}\right)$. Offsets for manure application in this scenario (1.0 $\mathrm{Mg} \mathrm{CO} \mathrm{C} \mathrm{ha}_{2} \mathrm{e}^{-1}$ ) came from reduced demand for commercial feed.

Application of inorganic $\mathrm{N}$ fertilizer also resulted in greenhouse gases emissions (Figure $2,4.0 \mathrm{Mg}$ $\left.\mathrm{CO}_{2} \mathrm{e} \mathrm{ha}{ }^{-1}\right)$. However, net emissions from the inorganic fertilizer were smaller than from the manure slurry. Like the other amendments, the inorganic fertilizer enhanced NPP resulting in both a $\mathrm{C}$ sink $\left(0.3 \mathrm{Mg} \mathrm{CO}_{2} \mathrm{e} \mathrm{ha}{ }^{-1}\right)$ and offsets from reduced commercial feed production (1.0 $\left.\mathrm{Mg} \mathrm{CO}_{2} \mathrm{e} \mathrm{ha}^{-1}\right)$.

\section{Case Studies with Alternative Ecosystem or Management Conditions}

Variables were modified to represent alternative scenarios, with notable impacts on the estimated net greenhouse gas flux from soil amendment applications (Figure 3). For example, increasing the $\mathrm{N}$ application rate of compost relative to the other amendments $(5 \times$ manure and $10 \times$ fertilizer rates) enabled a larger offset from waste diversion, leading to a net greenhouse gas flux of $110 \mathrm{MgCO}_{2} \mathrm{e} \mathrm{ha}^{-1}$ for compost over 3 years. Assuming that the NPP effect was sustained for 20 years increased the $C$ sink from all amendments to $1.9 \mathrm{Mg} \mathrm{CO}_{2} \mathrm{e} \mathrm{ha}^{-1}$ over
20 years; this $C$ accumulated over time through a fraction of the enhanced belowground biomass. The resulting net impact over 20 years was $24 \mathrm{Mg} \mathrm{CO}_{2} \mathrm{e} \mathrm{ha}{ }^{-1}$. If no increase in enteric fermentation occurred, then the net result was an even larger overall offset from compost $\left(30.9 \mathrm{Mg} \mathrm{CO}_{2} \mathrm{e}\right.$ $\mathrm{ha}^{-1}$ over 20 years). Changing the manure management system from a slurry to a low-emission stockpile $(E F=0.05)$ decreased the net offset from compost to $6.0 \mathrm{Mg} \mathrm{CO}_{2} \mathrm{e} \mathrm{ha}^{-1}$ over 3 years, whereas net emissions from manure applications decreased correspondingly. However, the manure amendment remained a larger source than the inorganic fertilizer (by $0.7 \mathrm{Mg} \mathrm{CO}_{2} \mathrm{e} \mathrm{ha}^{-1}$ ). Using the 20-versus 100-year GWP values for greenhouse gases roughly tripled the expected offset impact from compost (to $68.4 \mathrm{Mg} \mathrm{CO}_{2} \mathrm{e} \mathrm{ha}^{-1}$ ) and emissions impact from slurry storage and application (to $40.3 \mathrm{Mg} \mathrm{CO}_{2} \mathrm{e} \mathrm{ha}^{-1}$ ) over 3 years.

The results were sensitive to several of the model variables (Figure 4). Deviations from the initial case study values of $50 \%$ resulted in a change to the net greenhouse gas flux usually under $15 \mathrm{Mg} \mathrm{CO}_{2} \mathrm{e} \mathrm{ha}^{-1}$. One of the largest observed impacts in the sensitivity tests occurred when the compost- $\mathrm{N}$ concentration was reduced by $50 \%$, which corresponded to a need for more compost, a doubling of diverted waste, and an increase to offsets of over $20 \mathrm{Mg} \mathrm{CO}_{2} \mathrm{e} \mathrm{ha}{ }^{-1}$. The model was also quite sensitive to the manure management $\mathrm{EF}$, compost composition, and $\mathrm{N}$ addition rate, all of which led to a change of over $5 \mathrm{Mg} \mathrm{CO}_{2} \mathrm{e} \mathrm{ha}{ }^{-1}$

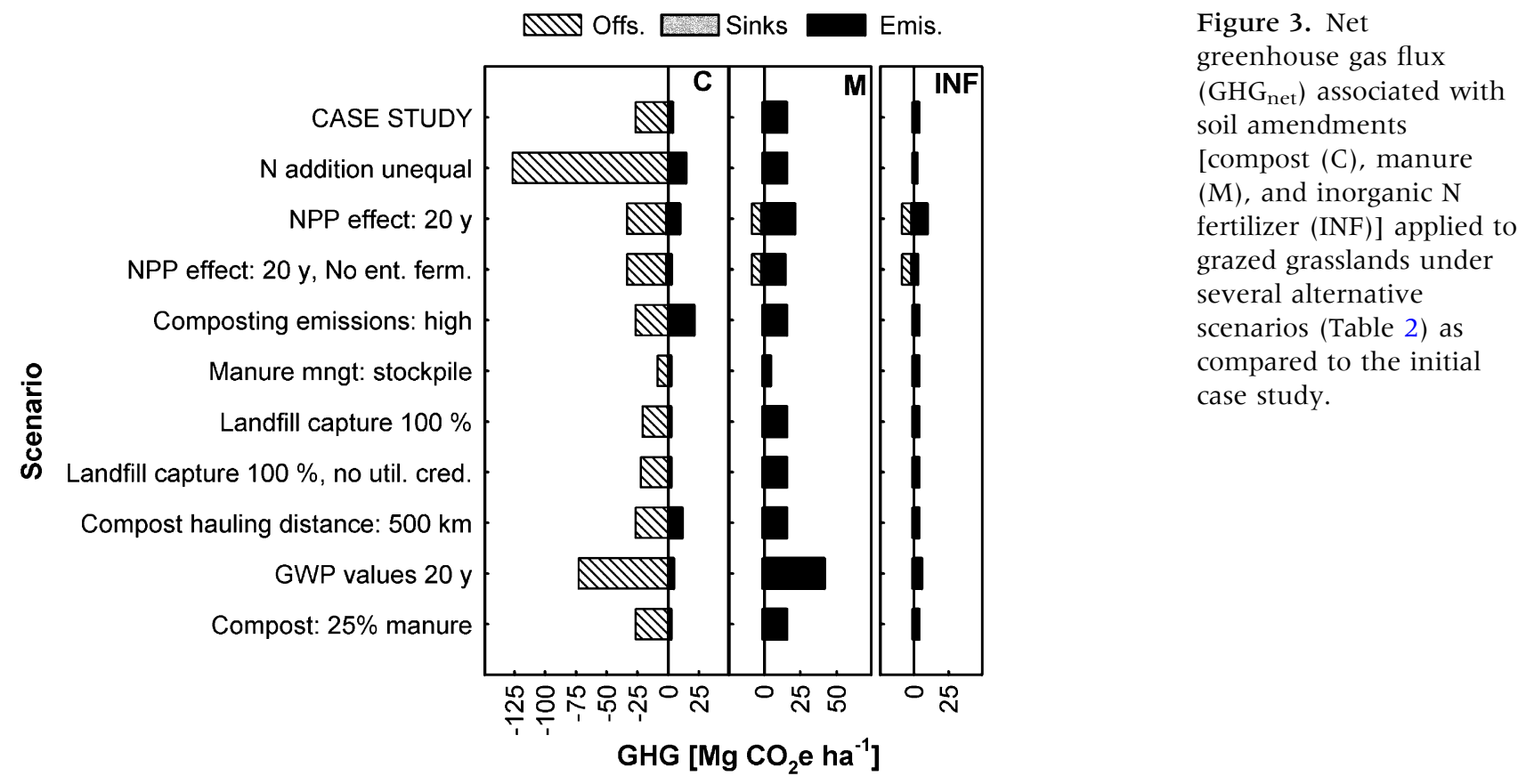




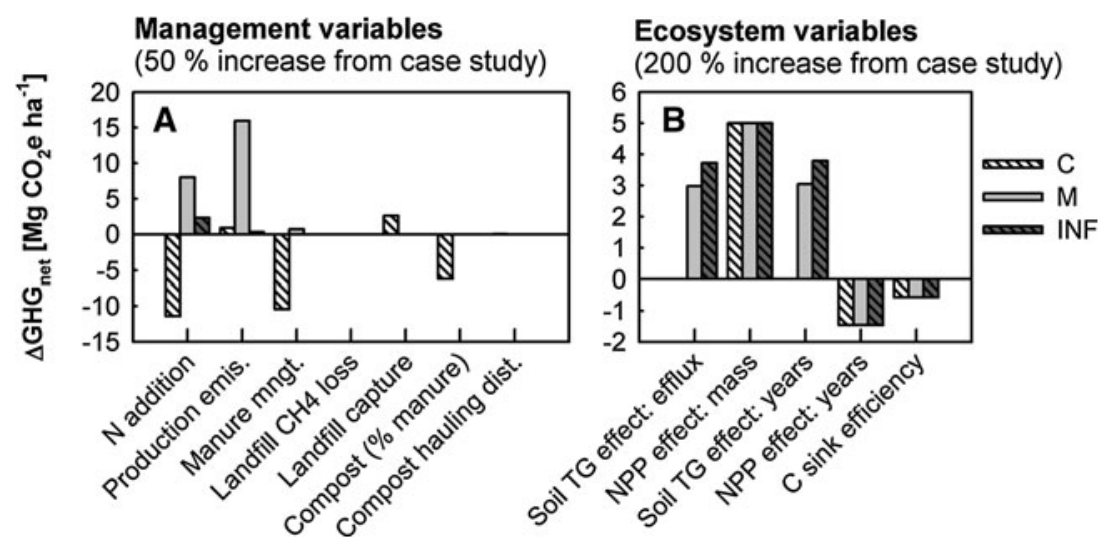

Figure 4. Change in net greenhouse gas flux $\left(\Delta \mathrm{GHG}_{\text {net }}\right)$ associated with soil amendment applications [compost $(\mathrm{C})$, manure (M), and inorganic N fertilizer (INF)] following A a 50\% increase to management variables or $\mathbf{B}$ a $200 \%$ increase to ecosystem variables (as compared to initial case study values). Additional results from the sensitivity analyses are shown in Appendix B (Supplementary Material).

following a $50 \%$ change. Results were less sensitive $\left(<5 \mathrm{Mg} \mathrm{CO}_{2} \mathrm{e} \mathrm{ha}^{-1}\right.$ response to a $50 \%$ change) to landfill emissions and $\mathrm{CH}_{4}$ capture rate. Results were not strongly dependent on hauling distances. Changes to most ecosystem variables (soil trace gas effluxes, NPP, C sink efficiency) had a small effect over the sensitivity test ranges.

When two ecosystem or management variables covaried, a broader range of potential impacts was observed (Figure 5). In cases where the manure content of compost was high $(>50 \%)$, results were particularly sensitive to the manure management EF (Figure 5A). When the full ranges of compost composition and manure management facilities were considered, compost amendment results reached a maximum net offset of $78.5 \mathrm{Mg} \mathrm{CO}_{2} \mathrm{e}$ $\mathrm{ha}^{-1}$. Compost materials largely derived from plant materials and high rates of landfill $\mathrm{CH}_{4}$ capture significantly decreased the greenhouse gas savings from composting (Figure 5B). As long as manure composed at least $25 \%$ of the compost, compost application led to net greenhouse gas emissions reduction at all landfill capture efficiency rates (up to $100 \%$ ). At $100 \%$ plant waste, capture efficiency rates below $80 \%$ were required to lead to a net greenhouse gas offset from compost application. On the other hand, at $100 \%$ plant waste but with no $(0 \%)$ landfill capture rate, composting led to net savings of $30 \mathrm{Mg} \mathrm{CO}_{2} \mathrm{e} \mathrm{ha}{ }^{-1}$. A capture rate of $100 \%$ with a utilities credit resulted in net emissions from compost relative to landfill (by $\left.12 \mathrm{Mg} \mathrm{CO}_{2} \mathrm{e} \mathrm{ha}{ }^{-1}\right)$; removing the utilities credit reduced the relative advantage of landfilling to $7 \mathrm{MgCO}_{2} \mathrm{e} \mathrm{ha}{ }^{-1}$.

Changes to two ecosystem variables had a smaller impact. In the initial case study, we assumed
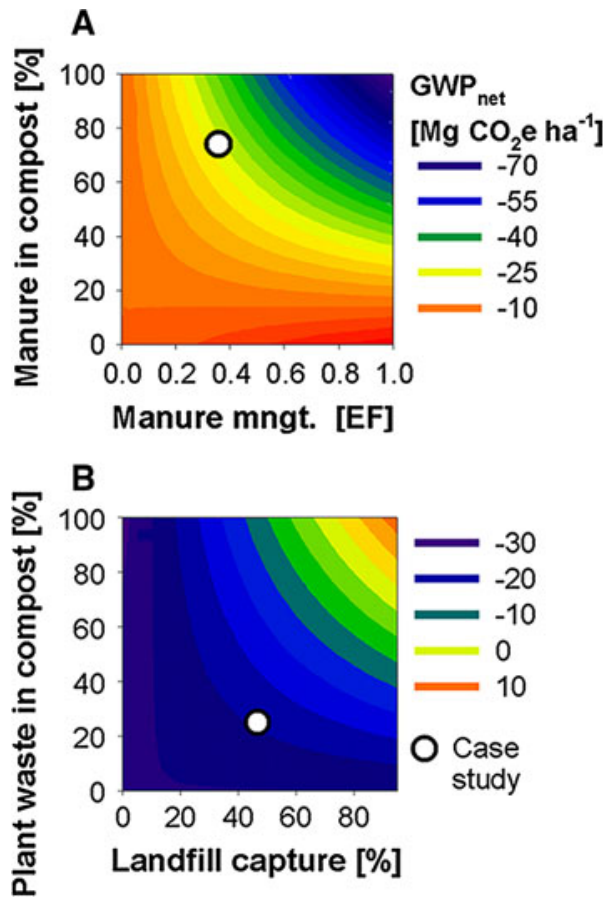

Figure 5. Range of possible net greenhouse gas flux $\left(\mathrm{GHG}_{\mathrm{net}}\right)$ resulting from the production and land application of compost amendments with different compositions and management conditions: A manure management emission factor (EF) and manure content, $\mathbf{B}$ landfill $\mathrm{CH}_{4}$ capture rate and plant waste content.

that NPP increased by $0.11 \mathrm{~kg} \mathrm{C} \mathrm{m}^{-2} \mathrm{y}^{-1}$ for 3 years. After increasing the magnitude and duration of the NPP effect, the net offset from composting reached over $100 \mathrm{Mg} \mathrm{CO}_{2} \mathrm{e} \mathrm{ha}{ }^{-1}$. We also initially assumed that $20 \%$ of the added belowground biomass $\mathrm{C}$ was stored in long-term soil $\mathrm{C}$ 
pools. In the case that $0 \%$ of added $\mathrm{C}$ was stored in these stable pools, the C sink attributed to NPP was lost. However, if $40 \%$ or more of this C is stored, then the cumulative effect could become significant, leading to additional savings of up to $10 \mathrm{Mg} \mathrm{CO}_{2} \mathrm{e} \mathrm{ha}^{-1}$ over 20 years.

\section{Uncertainty Analysis}

We performed a Monte Carlo analysis including 10,000 independent simulations based on the distributions of the variables with the greatest uncertainty (Table 3). This analysis suggested that application of compost to grazed grasslands is highly likely to lead to net greenhouse gas offsets, even when considering a much broader range of possible conditions (Figure 6). The average predicted net offset from compost was $4.3 \pm 0.8 \mathrm{Mg} \mathrm{CO}_{2} \mathrm{e} \mathrm{ha}^{-1}$. The findings for the manure and inorganic fertilizer treatments also generally agreed with the base case scenario. Manure and inorganic fertilizer applications were most likely to lead to net greenhouse gas emissions (17.2 \pm 0.7 and $\left.3.1 \pm 1.4 \mathrm{Mg} \mathrm{CO}_{2} \mathrm{e} \mathrm{ha}^{-1}\right)$. Although the uncertainty analysis agreed with the key findings from the initial case study, it also revealed that compost applications in some scenarios
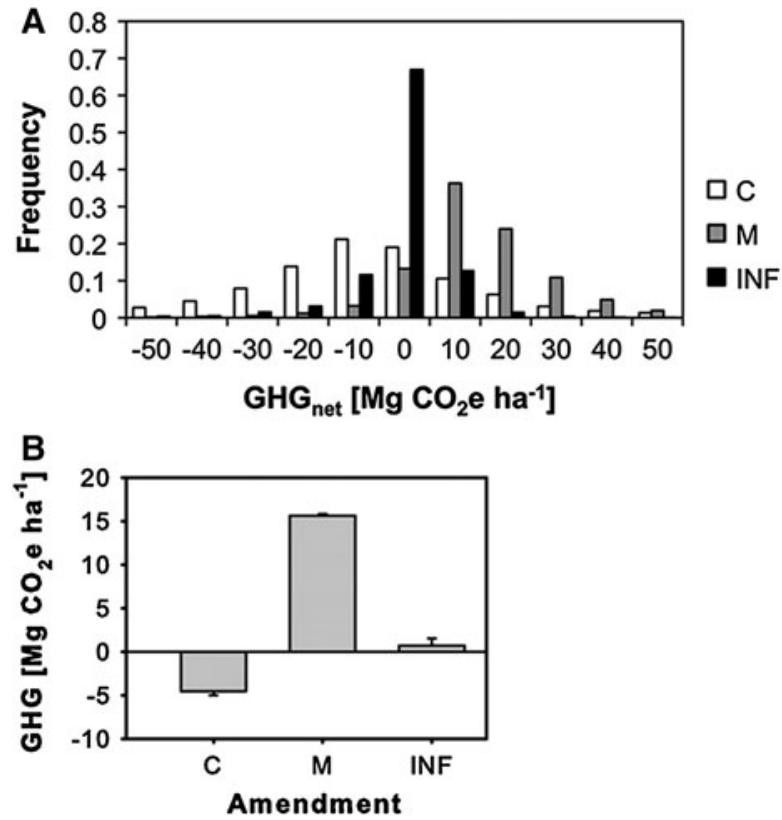

Figure 6. A Monte Carlo simulations $(n=10,000)$ showing the impact of uncertain and widely ranging variables on projected net greenhouse gas fluxes resulting from the application of compost $(\mathrm{C})$, manure $(\mathrm{M})$, or inorganic fertilizer (INF) to grasslands. B Mean and standard error of net greenhouse gas fluxes from 10,000 independent simulations of three soil amendment treatments. could lead to net emissions or that manure and inorganic fertilizer applications could potentially provide net offsets. For example, compost applications led to net emissions in cases where associated emissions were high (that is, due to poor management) but offsets were low (that is, materials were obtained from low-emission sources, ecosystem benefits were lower than expected). Alternatively, manure applications led to net offsets, but only if manure was handled in low-emission systems prior to land application and if measures were taken to minimize $\mathrm{N}$ losses after application. Although the model suggested that inorganic fertilizers could also potentially lead to net offsets, this was less likely due to the more ephemeral nature of these $\mathrm{N}$ inputs. Rapid N utilization and high loss rates led to a shorter period of beneficial ecosystem impacts that did not outweigh fertilizer production emissions over the long term.

\section{Upscaling}

We scaled up results to determine potential regional impacts of soil amendment-based management strategies (Table 4; Figure 7). Over a county-level region $(65,000 \mathrm{ha})$, compost applications as described in the initial case study led to a reduction in the net greenhouse gas flux of $1.5 \mathrm{MMg} \mathrm{CO}_{2} \mathrm{e}$ over 3 years. This is nearly equivalent to an offset of $10 \%$ of the annual emissions from the California commercial sector, which is the economic sector that includes categories such as food services, health care, education, and retail (CARB 2011). Extended to 5\% of California rangelands $(1,275,000 \mathrm{ha})$, this strategy would offset nearly 1 year of emissions from the California agriculture and forestry sectors (over $28 \mathrm{MMg} \mathrm{CO}_{2} \mathrm{e}, \mathrm{CARB} 2011$ ); although this estimate is based on 3 years of enhanced NPP, the majority of the benefit was obtained in the first year.

The availability of organic materials suitable for land application was assessed regionally and statewide (Table 4; Figure 7). Composted plant waste (including food) diverted from California landfills could be used to treat over 150,000 ha annually. Based on estimates of manure production, over 400,000 ha could also be treated annually with composted manure.

\section{Discussion}

Effects of Soil Amendments on Grassland $\mathrm{C}$ and Greenhouse Gases

The initial case study revealed that applying composted wastes to rangelands could significantly reduce greenhouse gas emissions attributed to the 
agricultural sector. At the field-scale, the net greenhouse gas offsets from compost per hectare of treated land were approximately equal to the greenhouse gas emissions of four trips of a diesel truck from San Francisco to Washington, DC (Graham and others 2008) or the annual $\mathrm{CH}_{4}$ emissions from eight grassfed cows (Laubach and Kelliher 2004). In contrast, the application of manure from slurry ponds, a common practice (EPA 2011 ; Meyer and others 2011), led to large greenhouse gas emissions.

The largest potential for greenhouse gas savings from compost amendments was due to diverting waste materials (both plant and manure wastes) from traditional high-emission waste management practices. The manure management factor used in the case study represented a slurry system where manure is liquefied. C-rich manure slurries facilitate the development of anaerobic conditions that stimulate $\mathrm{CH}_{4}$ production. The high $\mathrm{C}$ cost of $\mathrm{CH}_{4}$ emissions from the slurry system generally outweighed C gained via NPP and soil sequestration. It should be noted that other waste management strategies for manure such as anaerobic digestion with gas capture could help to reduce $\mathrm{CH}_{4}$ emissions relative to common liquid management systems. Similar to manure slurry systems, landfills typically experience anaerobic conditions that promote methanogenesis; rates depend on the physical and chemical properties of the waste and landfill environment, which is likely to vary over time and space. At landfills equipped with technologies to capture $\mathrm{CH}_{4}$ emissions, the benefits of organic waste diversion would be smaller relative to the default practice.
Diverting manure, yard and food wastes to composting systems can lead to significant greenhouse gas offsets. Unlike manure slurry systems and landfills, composting is specifically managed to promote aerobic decomposition by maintaining moisture content below saturation, providing
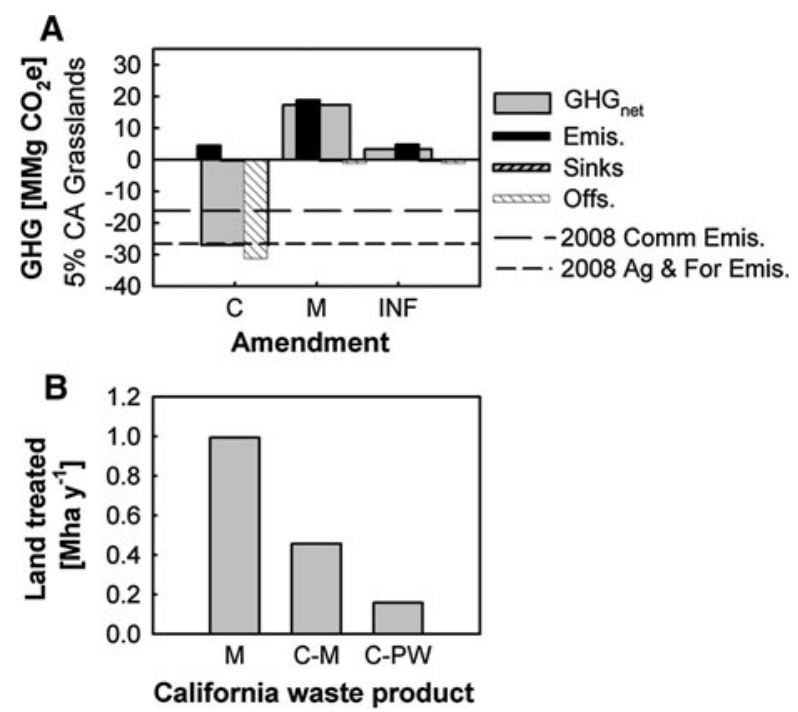

Figure 7. A Potential impacts of soil amendments on net greenhouse gas fluxes when applied over an area equal to $5 \%$ of California grasslands. Emissions from the California Agriculture and Forestry and Commercial Sectors (CARB 2011) are shown for comparison. B Area of land statewide that could potentially be treated annually using cattle manure $(\mathrm{M})$, composted manure $(\mathrm{C}-\mathrm{M})$, or composted plant waste (C-PW) assuming application rates used in the initial case study (Table 3) and material availability (Table 4).

Table 4. Resource Availability for Soil Amendment Production and Application

\begin{tabular}{|c|c|c|c|c|c|c|}
\hline & \multirow[t]{2}{*}{ Grassland (Mha) } & \multirow[t]{2}{*}{ Cattle (mill. head) } & \multirow[t]{2}{*}{ Cattle manure $^{\mathrm{a}}\left(\mathrm{MMg} \mathrm{Y}^{-1}\right)$} & \multicolumn{3}{|c|}{$\begin{array}{l}\text { Compostable waste at collection } \\
\text { facilities }^{\mathrm{b}, \mathrm{c}}\left(\mathrm{MMg} \mathrm{Y}^{-1}\right)\end{array}$} \\
\hline & & & & Yard waste & Food & Paper \\
\hline $\begin{array}{l}\text { Marin } \\
\text { CA } \\
\text { US }\end{array}$ & $\begin{array}{c}0.065^{\mathrm{d}} \\
24.0^{\mathrm{e}} \\
238.0^{\mathrm{f}}\end{array}$ & $\begin{array}{c}0.032^{\mathrm{g}} \\
5.2^{\mathrm{g}} \\
90.8^{\mathrm{h}}\end{array}$ & $\begin{array}{c}0.067 \\
10.8 \\
189.0\end{array}$ & $\begin{array}{c}0.025^{\mathrm{i}} \\
2.8^{\mathrm{j}} \\
33.4^{\mathrm{k}}\end{array}$ & $\begin{array}{c}0.054^{\mathrm{i}} \\
6.2^{\mathrm{j}} \\
34.8^{\mathrm{k}}\end{array}$ & $\begin{array}{c}0.077^{\mathrm{i}} \\
6.9^{\mathrm{j}} \\
71.3^{\mathrm{k}}\end{array}$ \\
\hline \multicolumn{7}{|c|}{$\begin{array}{l}\text { a Assuming a rate of } 2.08 \mathrm{Mg} \text { dry manure cow }{ }^{-1} y^{-1} \text { (USDA NRCS 2008). } \\
{ }^{b} \text { California and the US currently process greater than } 9.3 \mathrm{MMg} \text { (http://www.calrecycle.ca.gov/climate/Organics/default.htm) and greater than } 20 \mathrm{MMg} \text { (EPA 2011), waste, } \\
\text { respectively, into compost annually. } \\
{ }^{c} \text { Biosolids are also composted and could be included to increase compost production (Brown and Leonard 2004); approximately } 6.5 \mathrm{MMg} \text { of dry biosolids are produced } \\
\text { annually in the US (Lu and others 2012). } \\
{ }^{d} \text { Silver and others (2010). } \\
{ }^{2} \text { Brown and others (2004). } \\
{ }^{\prime} \text { Includes grassland pasture and range (Lubowski and others 2006); Avg US farm is } 170 \text { ha (USDA NASS 2012c). } \\
g \text { USDA NASS (2012a) (Milk cows: Marin-10,000, California-1,750,000). } \\
{ }^{h} \text { USDA NASS (2012b) (Milk cows: US-9,194,000). } \\
{ }^{i} \text { CalRecycle, Solid Waste Characterization Database: } 1999 \text { Data, available at: http://www.calrecycle.ca.gov/WasteChar/. } \\
{ }^{j} \text { CAIWMB (2009). }\end{array}$} \\
\hline
\end{tabular}


aeration, stimulating high temperatures, and decreasing labile $\mathrm{C}$ through high $\mathrm{C}: \mathrm{N}$ ratios. In theory, these conditions lead to low $\mathrm{CH}_{4}$ and $\mathrm{N}_{2} \mathrm{O}$ emissions, and, although results vary (Anderson and others 2010; Larney and Hao 2007; Hao and others 2004), emissions are generally lower than other waste management approaches. When we assumed significantly higher composting emissions, compost amendments still resulted in an overall greenhouse gas offset, although the magnitude was considerably lower. In the model, additional C benefits came from enhanced $\mathrm{C}$ sequestration through biomass, particularly when impacts on NPP lasted multiple years. A smaller offset came from a reduced need for purchased feed and the associated reduction in fertilizer, herbicide, and pesticide use. Although this was only a minor greenhouse gas savings, it can be crucial from an economic perspective, adding to the feasibility of these management approaches.

The predicted greenhouse gas impacts from compost, manure, and inorganic $\mathrm{N}$ fertilizers were influenced by emissions throughout the amendment life cycles. The manure management system was the primary cause for the high emissions from the manure amendment, whereas the landfill $\mathrm{CH}_{4}$ emissions and capture rates affected the outcome for compost amendments. These findings emphasize the importance of a thorough understanding of current practices (for manure management) and community resources (for landfill capabilities) when assessing the potential benefits of soil amendments. The greatest benefits from compost application are likely to be achieved in regions where either (1) high-emission manure management systems (slurry systems, lagoons) are widespread, or (2) large amounts of organic wastes are produced (for example, near urban and agricultural environments). Based on our parameterization of landfills and manure management, increasing the ratio of manure to plant waste in the compost increased the predicted greenhouse gas offset. This balance would shift depending upon local availability of materials, land, and infrastructure. The model can be used to explore the impact of these management practices on net greenhouse gas fluxes in regions with different resource availabilities.

\section{Soil Amendment Impacts in Alternative Scenarios}

Alternative scenarios were used to evaluate the outcomes from soil amendment applications under a wide range of environmental and management conditions. Results were most sensitive to the $\mathrm{N}$ application rate and amendment- $\mathrm{N}$ concentration. Together these variables determined the mass of materials used and, therefore, the magnitude of the offsets (compost) or emissions (manure, inorganic fertilizer). Although the initial case study assumed equal $\mathrm{N}$ additions, these amendments would likely be applied at different rates; composts, with slower rates of $\mathrm{N}$ mineralization, may be applied more heavily $\left(>1,000 \mathrm{~kg} \mathrm{ha}^{-1}\right)$ than inorganic fertilizers, which are often used more sparingly $\left(<250 \mathrm{~kg} \mathrm{ha}^{-1}\right.$, Bouwman and others 2002). Changing these rates accordingly enables greater waste diversion for compost, increasing the associated greenhouse gas offset, even when accounting for processing and transportation. It is likely that there would be different impacts on NPP if N application rates were unequal among the amendments, leading to additional relative benefits for the compost, particularly if the NPP effect is sustained over a decade or more. For example, the initial case study assumed that equal $\mathrm{N}$ additions led to equal benefits (magnitude and duration of enhanced NPP) from all amendments. However, compost differs from manure and inorganic fertilizer in that it is partially decomposed and has a high proportion of complexed or recalcitrant materials (Eghball 2000). These materials break down more slowly than fresh residues, acting as a slow release fertilizer (Eghball 2000; Sikora and Szmidt 2001). This mechanism is likely to sustain NPP for longer time periods than, for instance, a short pulse of inorganic fertilizer (Sullivan and others 1998).

Manure amendments were associated with larger greenhouse gas emissions than inorganic fertilizers, despite the additional energy cost required for synthetic fertilizer production. Although the energy costs of producing inorganic fertilizer were not negligible, emissions from production were lower than other emissions attributed to fertilizer use, such as soil $\mathrm{N}_{2} \mathrm{O}$ emissions (Adler and others 2007). Additionally, a smaller mass of inorganic fertilizer was required to achieve the same $\mathrm{N}$ application rates.

The inorganic fertilizer did not use any waste materials, unlike compost and manure. For manure, we estimated emissions from storage prior to application and included these estimates in the total greenhouse gas emissions. In contrast, for the compost, we considered a diversion of manure to be an offset as compared to the uncomposted manure application (considered the current default practice). For inorganic N, we considered the case where manure was a limited resource and unavailable. These boundaries were designed to weigh the production costs of inorganic fertilizer 
against the potential ecosystem benefits. If inorganic $\mathrm{N}$ fertilizer was used in a location where manure was available, emissions from manure storage and management would also need to be considered; in this scenario, net emissions from inorganic fertilizer would likely exceed the emissions from manure application.

The impacts of soil amendments on several ecosystem properties were also areas of uncertainty in the model. Nitrogen losses from ecosystems, either directly as $\mathrm{N}_{2} \mathrm{O}$ or indirectly through leachate and volatilization, depend on the quantity, chemical quality, and application method of amendments, as well as ecosystem conditions (for example, soil moisture, drainage, temperature, $\mathrm{pH}$; Lesschen and others 2011; Stehfest and Bouwman 2006). We applied widely used EFs for manure and inorganic $\mathrm{N}$ fertilizers, but these values should ideally be determined specifically for each site (De Klein and others 2006; Kendall and Chang 2009). Minimizing $\mathrm{N}_{2} \mathrm{O}$ losses for quick-release fertilizers and manure can require multiple, rather than one-time applications, increasing emissions associated with transportation. Therefore, the case studies may have underestimated net greenhouse gas fluxes associated with manure and inorganic fertilizer applications. On the other hand, enhanced efficiency inorganic fertilizers (that is, with nitrification inhibitors and polymercoated fertilizers) have the potential to decrease greenhouse gas emissions relative to conventional inorganic fertilizers (Akiyama and others 2010). In addition to impacts on soil $\mathrm{N}_{2} \mathrm{O}$ emissions, recent research suggests that compost additions could lower soil $\mathrm{CH}_{4}$ emissions (Chen and others 2011) or minimize $\mathrm{CH}_{4}$ uptake inhibition (Mosier and others 1991). If compost can provide ecosystem benefits without decreasing $\mathrm{CH}_{4}$ oxidation, this could improve the strength of the compost greenhouse gas emissions offset relative to other amendments.

\section{Considerations for Widespread Adoption}

The greenhouse gas benefits of soil amendments can be significant when materials are diverted from waste streams and applied to the land. We focused on specific regions in California, although our model can be applied on larger national or even global scales. The large-scale applicability of these ideas is due to the ubiquity of grasslands, grazing, and waste management concerns.

The relatively small impact of transportation on the amendment net greenhouse gas flux indicates that these practices could be adopted over larger regions. Low relative $\mathrm{C}$ costs of transportation have been found in other analyses (Weber and
Matthews 2008). Local projects would be the most logical and least expensive; however, our results suggest that small additional $C$ costs to move waste materials to suitable land would not strongly impact the offset potential from composting.

These results are dependent on the GWP values, which represent the long-term atmospheric impacts of key greenhouse gases. The difference between the results for manure and compost using 20-year rather than 100-year GWP values was striking. When focusing on a shorter timescale, the impact of offsets from diverting waste for compost more than doubled (to nearly $100 \mathrm{Mg} \mathrm{CO}_{2} \mathrm{e} \mathrm{ha}^{-1}$ ). The 100-year values for GWP are the most commonly used. These values are somewhat arbitrary from an ecosystem perspective and our analyses illustrate the significant effect that these assumptions could have on management and policy decisions.

Overall, this study has demonstrated that producing compost and applying it to rangelands has the potential to significantly offset GHG emissions. As the largest offsets were obtained from the diversion of materials from high-emission waste streams, this study also generally highlights the opportunity to mitigate greenhouse gas emissions by improving waste management. In the case of compost, using existing waste materials and land area could lead to significant offsets annually, with numerous co-benefits also achieved. Climate mitigation benefits from this practice are likely to be greatest when it is applied near rural or urban centers where high-emission manure management systems are common or where large amounts of organic materials could be diverted from landfills. Increased forage production and soil quality, though not the primary drivers of the mitigation potential, provide important co-benefits and incentives to land managers. The model can be applied broadly to identify the potential for grassland management to mitigate climate change in regions with different resources and ecosystem characteristics.

\section{ACKNOWLEDGMENTS}

This research was possible thanks to funding from the Marin Community Foundation, Rathmann Family Foundation, Lia Fund, Conservation Innovation Grant from the USDA to Environmental Defense Fund, and the Kearney Foundation for Soil Science. We are grateful to John Wick, Jeffrey Creque, and Peggy Rathmann for their contributions to both the fieldwork and many discussions that were useful in developing the concepts used in 
this study. We also thank the Marin Agricultural Land Trust, and N. Scolari, B. Berner, P. Hickey, D. Lewis, S. Larson, S. Carlsen, T. Estrada, C. Epifano, and Marin Organic for their partnership in the Marin Carbon Project. J. Neff and two anonymous reviewers provided insightful feedback that improved the manuscript.

\section{OPEN ACCESS}

This article is distributed under the terms of the Creative Commons Attribution License which permits any use, distribution, and reproduction in any medium, provided the original author(s) and the source are credited.

\section{REFERENCES}

Adler PR, Del Grosso SJ, Parton WJ. 2007. Life cycle assessment of net greenhouse gas flux for bioenergy cropping systems. Ecol Appl 17(3):675-91.

Akiyama H, Yan X, Yagi K. 2010. Evaluation of effectiveness of enhanced-efficiency fertilizers as mitigation options for $\mathrm{N}_{2} \mathrm{O}$ and NO emissions from agricultural soils: meta-analysis. Glob Change Biol 16(6):1837-46.

Allard V, Soussana J-F, Falcimagne R, Berbigier P, Bonneford JM, Ceschia E, D'hour P, Henault C, Lavelle P, Martin C, Pinares-Patino C. 2007. The role of grazing management for the net biome productivity and greenhouse gas budget $\left(\mathrm{CO}_{2}\right.$, $\mathrm{N}_{2} \mathrm{O}$, and $\mathrm{CH}_{4}$ ) of semi-natural grassland. Agric Ecosyst Environ 121:47-58.

Anderson JK, Boldrin A, Christensen TH, Scheutz C. 2010. Mass balances and life-cycle inventory for a garden waste windrow composting plant (Aarhus, Denmark). Waste Manag Resour 28:1010.

Asner GP, Elmore AJ, Olander LP, Martin RE, Harris AT. 2004. Grazing systems, ecosystem responses, and global change. Annu Rev Environ Resour 29:261-99.

Bai ZG, Dent DL, Olsson L, Schaepman ME. 2008. Global assessment of land degradation and improvement. 1. Identification by remote sensing. Report 2008/01. Wageningen: ISRIC-World Soil Information.

Beer T, Grant T, Williams D, Watsond H. 2002. Fuel-cycle greenhouse gas emissions from alternative fuels in Australian heavy vehicles. Atmos Environ 36:753-63.

Benbrook C, Carman C, Clark EA, Daley C, Fulwider W, Hansen M, Leifert C, Martens K, Paine L, Petkewitz L, Jodarski G, Thicke F, Velez J, Wegner G. 2010. A dairy farms footprint: evaluating the impacts of conventional and organic farming systems. Boulder (CO): The Organic Center.

Boadi DA, Wittenberg KM, Scott SL, Burton D, Buckley K, Small JA, Ominski KH. 2004. Effect of low and high forage diet on enteric and manure pack greenhouse gas emissions from a feedlot. Can J Animal Sci 84:445-53.

Bodelier PLE, Laanbroek HJ. 2004. Nitrogen as a regulator factor of methane oxidation in soils and sediments. FEMS Microbiol Ecol 47:265-77.

Bouwman AF, Boumans LJM, Batjes NH. 2002. Emissions of $\mathrm{N}_{2} \mathrm{O}$ and $\mathrm{NO}$ from fertilized fields: summary of available measurement data. Glob Biogeochem Cycles 16(4):1058.
Bridges EM, Oldeman LR. 1999. Global assessment of humaninduced soil degradation. Arid Soil Res Rehabil 13:319-25.

Brown S, Dushku A, Pearson T, Shoch D, Winsten J, Sweet S, Kadyszewski J. 2004. Carbon supply from changes in management of forest, range, and agricultural lands of California. Arlington (VA): Winrock International, for the California Energy Commission, PIER Energy-Related Environmental Research, 500-04-068F.

Brown S, Krueger C, Subler S. 2008. Greenhouse gas balance for composting operations. J Environ Qual 37:1396-410.

Brown S, Kurtz K, Bary A, Cogger C. 2011. Long-term effects of organic amendments on soil carbon storage and physical properties. Environ Sci Technol . doi:10.1021/es2010418.

Brown S, Leonard P. 2004. Building carbon credits with biosolids recycling. BioCycle 45(9):25-9.

CA Integrated Waste Management Board (CAIWMB). 2009. Contractor's report to the board: California 2008 statewide waste characterization study. Sacramento (CA): CAIWMB. www.calrecycle.ca.gov/publications/general/2009023.pdf. Accessed July 2012.

Cabrera VE, Stavast LJ, Baker TT, Wood MK, Cram DS, Flynn RP, Ulery AL. 2009. Soil and runoff response to dairy manure application on New Mexico rangeland. Agric Ecosyst Environ 131:255-62.

California Air Resources Board (CARB). 2011. California greenhouse gas inventory for 2000-2009-by sector and activity. Sacramento (CA): CARB. http://www.arb.ca.gov/cc/ inventory/data/data.htm. Accessed July 2012.

California Department of Transportation (CDOT). 2012. Truck restriction procedures. Sacramento (CA): CDOT. www.dot.ca. gov/hq/traffops/trucks/routes/restrict-process.htm. Accessed July 2012.

Cavigelli MA, Djurickovic M, Rasmann C, Spargo JT, Mirsky SB, Maul JE. 2009. Global warming potential of organic and conventional grain cropping systems in the Mid-Atlantic Region of the US. In: Proceedings of the Farming System Design Conference. p 51-2.

Chen R, Lin X, Wang Y, Hu J. 2011. Mitigating methane emissions from irrigated paddy fields by application of aerobically composted livestock manures in eastern China. Soil Use Manag 27:103-9.

Conant RT. 2011. Sequestration through forestry and agriculture. WIREs Clim Change 2:238-54.

Conant RT, Paustian K, Elion ET. 2001. Grassland management and conversion into grassland: effects on soil carbon. Ecol Appl 11(2):343-55.

Dalai RC, Gibson IR, Menzies NW. 2009a. Nitrous oxide emission from feedlot manure and green waste compost applied to vertisols. Biol Fertil Soils 45:809-19.

Dalai RC, Gibson IR, Allen DE, Menzies NW. 2009b. Green waste compost reduces nitrous oxide emissions from feedlot manure applied to soil. Agric Ecosyst Environ 136(3-4):273-81.

Davidson EA. 2009. The contribution of manure and fertilizer nitrogen to atmospheric nitrous oxide since 1860. Nat Geosci 2:659-62.

Davis J, Haglund C. 1999. Life cycle inventory (LCI) of fertilizer production: fertiliser products used in Sweden and Western Europe. SIK-Report No. 654. Masters Thesis, Chalmers University of Technology.

De Klein C, Novoa RSA, Ogle S, Smith KA, Rochette P, Wirth TC. 2006. $\mathrm{N}_{2} \mathrm{O}$ emissions from managed soils, and $\mathrm{CO}_{2}$ emissions from lime and urea application. In: Eggleston S, Buendia 
L, Miwa K, Ngara T, Tanabe K, Eds. Intergovernmental panel on climate change. 2006 IPCC guidelines for national greenhouse gas inventories, Vol. 4. Agriculture, forestry and other land use. Japan: IGES.

Del Grosso SJ, Parton WJ, Mosier AR, Ojima DS, Potter CS, Borken W, Brumme R, Butterbach-Bahl K, Crill PM, Dobbie K, Smith KA. 2000. General $\mathrm{CH}_{4}$ oxidation model and comparisons of $\mathrm{CH}_{4}$ oxidation in natural and managed systems. Glob Biogeochem Cycles 14:999-1019.

Diacono M, Montemurro F. 2010. Long-term effects of organic amendments on soil fertility: a review. Agron Sustain Dev 30:401-22.

Dong $\mathrm{H}$, Mangino J, McAllister T, Hatfield JL, Johnson DE, Lassey KR, Aparecida de Lima M, Romanovskaya A. 2006. Emissions from livestock and manure management. In: Eggleston $S$ et al., Eds. Intergovernmental panel on climate change. 2006 IPCC guidelines for national greenhouse gas inventories, Vol. 4. Agriculture, forestry and other land use. http://www.ipcc-nggip.iges.or.jp/public/2006gl/pdf/4_Volume4/ V4_10_Ch10_Livestock.pdf. Accessed July 2012.

Downs HW, Hansen RW. 1998. Estimating farm fuel requirements. Fact Sheet No. 5.006. Colorado State University Extension. www.ext.colostate.edu/pubs/farmmgt/05006.pdf. Accessed July 2012.

Eghball B. 2000. Nitrogen mineralization from field-applied beef cattle feedlot manure or compost. Soil Sci Soc Am J 64:202430.

Eleazer WE, Odle WS, Wang Y-S, Barlaz MA. 1997. Biodegradability of municipal solid waste components in laboratory-scale landfills. Environ Sci Technol 31:911-17.

Ellis JL, Kerbreab E, Odongo NE, McBride BW, Okine EK, France J. 2007. Prediction of methane production from dairy and beef cattle. J Dairy Sci 90(7):3456-66.

Ellis JL, Bannick A, France J, Kebreab E, Dijkstras J. 2010. Evaluation of enteric methane prediction equations for dairy cows used in whole farm models. Glob Change Biol 16:3246-56.

Environmental Protection Agency (EPA). 2006. Solid waste management and greenhouse gases. A life-cycle assessment of emissions and sinks. 3rd edn. San Francisco (CA): EPA. www. epa.gov/climatechange/wycd/waste/downloads/fullreport.pdf. Accessed July 2012.

Environmental Protection Agency (EPA). 2008. Direct emissions from mobile combustion sources. EPA430-K-08-004. San Francisco (CA): EPA. www.epa.gov/climateleadership/documents/resources/mobilesource_guidance.pdf. Accessed July 2012.

Environmental Protection Agency (EPA). 2011. Municipal solid waste generation, recycling, and disposal in the United States: facts and figures for 2010. EPA-530-F-11-005. San Francisco (CA): EPA. www.epa.gov/osw/nonhaz/municipal/pubs/msw_ 2010_factsheet.pdf. Accessed July 2012.

Environmental Protection Agency (EPA). 2012a. Chapter 8. Waste. Inventory of US greenhouse gas emissions and sinks: 1990-2010. San Francisco (CA): EPA. http://www.epa.gov/ climatechange/ghgemissions/usinventoryreport.html. Accessed July 2012.

Environmental Protection Agency (EPA). 2012b. Annex 3.10. Methodology for estimating $\mathrm{CH}_{4}$ and $\mathrm{N}_{2} \mathrm{O}$ emissions from manure management. Inventory of US greenhouse gas emissions and sinks: 1990-2010. San Francisco (CA): EPA. p 235-57. http://www.epa.gov/climatechange/ghgemissions/ usinventoryreport.html. Accessed July 2012.
Food and Agricultural Organization of the United Nations (FAO). 2011. The state of the world's land and water resources for food and agriculture: managing systems at risk. Rome: FAO. www.fao.org/nr/water/docs/SOLAW_EX_SUMM_WEB_EN.pdf. Accessed July 2012.

Fukumoto Y, Suzuki K, Osada T, Kuroda K, Hanajima D, Yasuda T, Haga K. 2006. Reduction of nitrous oxide emission from pig manure composting by addition of nitrite-oxidizing bacteria. Environ Sci Technol 40:6787-91.

Glatzel S, Stahr K. 2001. Methane and nitrous oxide exchange in differently fertilised grassland in southern Germany. Plant Soil 231:21-35.

Graham LA, Rideout G, Rosenblatt D, Hendren J. 2008. Greenhouse gas emissions from heavy-duty vehicles. Atmos Environ 42:4665-81.

Hao X, Chang C, Larney FJ. 2004. Carbon, nitrogen balances and greenhouse gas emission during cattle feedlot manure composting. J Environ Qual 33:37-44.

Harpole WS, Potts DL, Suding KN. 2007a. Ecosystem responses to water and nitrogen amendment in a California grassland. Glob Change Biol 13:2341-8.

Harpole WS, Goldstein L, Aicher R. 2007b. Resource limitation. In: D'Antonio C, Corbin J, Stromberg M, Eds. Ecology and management of California grassland. Berkeley: University of California Press. p 119-27.

Holecheck JL, Gomez H, Molinar F, Galt D. 1999. Grazing studies: what we've learned. Rangelands 21:12-16.

Hudson BD. 1994. Soil organic matter and available water capacity. J Soil Water Conserv 49(2):189-94.

Intergovernmental Panel on Climate Change (IPCC). 2007. Contribution of Working Group I to the fourth assessment report of the Intergovernmental Panel on Climate Change. In: Solomon S, Qin D, Manning M, Chen Z, Marquis M, Averyt KB, Tignor M, Miller HL, Eds. Climate change 2007: the physical science basis. Cambridge: Cambridge University Press.

Katterer T, Bolinder MA, Andren O, Kirchmann H, Menichetti L. 2011. Roots contribute more to refractory soil organic matter than above-ground crop residues, as revealed by a long-term field experiment. Agric Ecosyst Environ 141:184-92.

Kendall A, Chang B. 2009. Estimating life cycle greenhouse gas emissions from corn-ethanol: a critical review of current U.S practices. J Clean Prod 17:1175-82.

Kramer SB, Reganold JP, Glover JD, Bohannan BJM, Mooney HA. 2006. Reduced nitrate leaching and enhanced denitrified activity and efficiency in organically fertilized soils. Proc Natl Acad Sci 103:4522-7.

Lal R. 2004a. Soil carbon sequestration impacts on global climate change and food security. Science 304(5677):1623-7.

Lal R. 2004b. Soil carbon sequestration to mitigate climate change. Geoderma 123:1-22.

Lal R. 2004c. Carbon emission from farm operations. Environ Int 30:981-90.

Larney FJ, Hao X. 2007. A review of composting as a management alternative for beef cattle feedlot manure in southern Alberta, Canada. Bioresour Technol 98(17):3221-7.

Larney FJ, Elson EF, Carcamo AA, Chang C. 2000. Physical changes during active and passive composting of beef feedlot manure in winter and summer. Bioresour Technol 75(2):139-48.

Laubach J, Kelliher FM. 2004. Measuring methane emission rates of a dairy by two micrometeorological techniques. Agric For Meteorol 125:279-303. 
Le Mer J, Roger P. 2001. Production, oxidation, emission and consumption of methane by soils: a review. Eur J Soil Biol $37: 25-50$

Lesschen JP, Velthof GL, deVries W, Kross J. 2011 . Differentiation of nitrous oxide emission factors from agricultural soils. Environ Pollut 159(11):3215-22.

Lu Q, He ZL, Stoffella PJ. 2012. Land application of biosolids in the USA: a review. Appl Environ Soil Sci. doi:10.1155/2012/ 201462.

Lubowski RN, Vesterby M, Bucholtz S, Baez A, Roberts MJ. 2006. Major uses of land in the United States, 2002. Economic Information Bulletin 14. Washington (DC): US Department of Agriculture.

McDowell RW, Dou Z, Toth JD, Cade-Menun BJ, Kleinman PJA, Soder K, Saporito L, USDA, ARS. 2008. A comparison of phosphorus speciation and potential bioavailability in feed and feces of different dairy herds using $31 \mathrm{P}$ nuclear magnetic resonance spectroscopy. J Environ Qual 37(3):741-52.

Meyer D, Prince PL, Rossow HA, Silva-delRio N, Karle MM, Robinson PH, DePeters EJ, Fadel JG. 2011. Survey of dairy housing and manure management practices in California. $\mathrm{J}$ Dairy Sci 94(9):4744-50.

Mosier AR, Schimel D, Valentine D, Bronson K, Parton W. 1991. Methane and nitrous oxide fluxes in native, fertilised and cultivated grasslands. Nature 350:330-2.

Mosier A, Kroeze C, Nevison C, Oenema O, Seitzinge S, van Cleemput O. 1998. Closing the global $\mathrm{N}_{2} \mathrm{O}$ budget: nitrous oxide emissions through the agricultural nitrogen cycle. Nutr Cycl Agroecosyst 52:225-48.

Paul JW, Beauchamp EG, Zhang X. 1993. Nitrous and nitric oxide emissions during nitrification and denitrification from manureamended soil in the laboratory. Can J Soil Sci 73:539-53.

Paustian K, Collins HP, Paul EA. 1997. Management controls on soil carbon. In: Paul EA, Paustian K, Elliot ET, Cole CV, Eds. Soil organic matter in temperate agroecosystems. Boca Raton (FL): CRC Press. p 15-49.

Pitesky RE, Stackhouse KR, Mitloehner FM. 2009. Chapter l-clearing the air: livestock's contribution to climate change. Adv Agron 103:1-40.

Plénet D, Lubet E, Juste C. 1993. Évolution à long terme du statut carboné du sol en monoculture non irriguée du maïs (Zea mays L.). Agronomie 13:685-98.

Potter P, Ramankutty N, Bennett EM, Donner SD. 2010. Characterizing the spatial patterns of global fertilizer application and manure production. Earth Interact 14(2):1-22.

Powell MJ, Jackson D, Satter L. 2002. Phosphorus feeding and manure nutrient content recycling on Wisconsin dairy farms. Nutr Cycl Agroecosyst 62:277-86.

Rotz A, Montes F, Chianes DS. 2010. The carbon footprint of dairy production systems through partial life cycle assessment. J Dairy Sci 93:1266-82.

Ryals R, Silver WL. 2013. Effects of organic matter amendments on net primary productivity and greenhouse gas emissions in annual grasslands. Ecol Appl 23:46-59.

Ryals R, Hartman M, Parton WJ, DeLonge MS, Silver WL. Shortterm grassland management practices have multi-decadal effects on ecosystem carbon and greenhouse gas dynamics. Glob Change Biol (in review-a).

Ryals R, Kaiser M, Torn MS, Berhe AA, Silver WL. Impacts of organic matter amendments on carbon and nitrogen dynamics in grassland soils. Soil Biol Biochem (in review-b).
Rynk R. 1992. On-farm composting handbook, volume 54 of NRAES (Natural Resource Agriculture, and Engineering Service). Ithaca (NY): PALS Publishing.

Sanderman J, Baldock JA. 2010. Accounting for soil carbon sequestration in national inventories: a soil scientist's perspective. Environ Res Lett 5:034003.

Sikora LJ, Szmidt RAK. 2001. Nitrogen sources, mineralization rates, and nitrogen nutrition benefits to plants from composts. In: Stoffella PJ, Kah BL, Eds. Compost utilization in horticultural cropping systems. Florida: CRC Press LCC. p 287-306.

Silver WL, Ryals R, Eviner V. 2010. Soil carbon pools in California's annual grassland ecosystems. Rangeland Ecol Manage 63:128-136.

Smith P, Martino D, Cai Z, Gwary D, Janzen H, Kumar P, McCarl B, Ogle S, O'Mara F, Rice C, Scholes B, Sirotenko O, Howden M, McAllister T, Pan G, Romanenkov SchneiderU, Towprayoon S, Wattenbach M, Smith J. 2008. Greenhouse gas mitigation in agriculture. Philos Trans R Soc Lond Ser B Biol Sci 363:789-813.

Stavast LJ, Baker TT, Ulery AL, Flynn RP, Wood MK, Cram DS. 2005. New Mexico blue grama rangeland response to dairy manure application. Rangel Ecol Manag 58:423-9.

Stehfest E, Bouwman L. 2006. $\mathrm{N}_{2} \mathrm{O}$ and $\mathrm{NO}$ emission from agricultural fields and soils under natural vegetation: summarizing available measurement data and modeling of global annual emissions. Nutr Cycl Agroecosyst 74(3):207-28.

Stout WL, Fales SL, Muller LD, Schnabel RR, Elwinger GF, Weaver SR. 2000. Assessing the effect of management intensive grazing on water quality in the northeast US. J Soil Water Conserv 55(2):238-43.

Sullivan DM, Fransen SC, Bary AI, Cogger CG. 1998. Slow-release nitrogen from composts: the bulking agent is more than fluff. In: Brown S, Angle JS, Jacobs L, Eds. Beneficial co-utilization of agricultural, municipal and industrial byproducts. Dordrecht: Kluwer. p 319-25.

Tenuta M, Mkhabela D, Tremorin L, Coppi G, Phipps D, Flaten KOminski. 2010. Nitrous oxide and methane emissions from a coarse-textured grassland soil receiving hog slurry. Agric Ecosyst Environ 138(2010):35-43.

Tian G, Granato TC, Cox AE, Pietz RI, Carlson CR Jr, Abedin Z. 2009. Soil carbon sequestration resulting from long-term application of biosolids for land reclamation. J Environ Qual 38:61-74.

US Department of Agriculture National Agricultural Statistics Service (USDA NASS). 2009. 2007 Census of agriculture. Sacramento (CA): USDA NASS. http://www.agcensus.usda. gov/Publications/2007/Full_Report/. Accessed July 2012.

US Department of Agriculture National Agricultural Statistics Service (USDA NASS). 2011. Quick stats. Sacramento (CA): USDA NASS. http://quickstats.nass.usda.gov/. Accessed June 2011.

US Department of Agriculture National Agricultural Statistics Service (USDA NASS). 2012a. 2010 California livestock county estimates. Sacramento (CA): USDA NASS. http://www.nass. usda.gov/Statistics_by_State/California/Publications/County_ Estimates/index.asp. Accessed July 2012.

US Department of Agriculture National Agricultural Statistics Service (USDA NASS). 2012b. 2011 Cattle inventory. Sacramento (CA): USDA NASS. http://usda.mannlib.cornell.edu/ MannUsda/viewDocumentInfo.do?documentID=1017. Accessed July 2012. 
US Department of Agriculture National Agricultural Statistics Service (USDA NASS). 2012c. Farms, land in farms, and livestock operations 2011 summary. Sacramento (CA): USDA NASS.

US Department of Agriculture National Resources Conservation Service (USDA NRCS). 2008. Chapter 4. Agricultural waste characteristics. Part 651 Agricultural waste management field handbook. Washington, DC: USDA NRCS. http://policy.nrcs.usda.gov. Accessed July 2012
Weber CL, Matthews HS. 2008. Food-miles and the relative climate impacts of food choices in the United States. Environ Sci Technol 42:3508-13.

West TO, Marland G. 2002. A synthesis of carbon sequestration, carbon emissions, and net carbon flux in agriculture: comparing tillage practices in the United States. Agr Ecosyst Environ 91:217-23.

Wood S, Cowie A. 2004. A review of greenhouse gas emission factors for fertiliser production. IEA Bioenergy Task 38. Paris: IEA. 